\title{
La culpabilidad y los sujetos responsables en las infracciones de tráfico*
}

\author{
Tomás Cano Campos \\ Profesor Titular de Derecho Administrativo \\ Universidad Complutense de Madrid
}

\begin{abstract}
Resumen
El artículo de Tomás Cano Campos trata de ligar unánimemente los conceptos: culpabilidad y sanción administrativa siendo este último concepto principio del Derecho administrativo sancionador.

Cano Campos presenta en este texto los diversos significados del concepto "culpabilidad/dolo/culpa" distinguibles por el contexto de aplicación legislativa, que además está claramente diferenciado por el autor: infracciones administrativas (responsabilidad personal y por el hecho, responsabilidad subjetiva e imputación o culpabilidad en sentido estricto) e infracciones de tráfico (responsabilidad parental ante las infracciones de los menores de edad, responsabilidad en los supuestos de no identificación del conductor, infracciones relativas a vehículos, responsabilidad subsidiaria no sancionadora, imputación personal o reprochabilidad, minoría de edad y trastorno psíquico e imputación por consumo de alcohol).
\end{abstract}

Palabras clave Derecho penal; Derecho administrativo; Derecho administrativo sancionador; Infracciones administrativas; Infracciones de tráfico; Responsabilidad administrativa; Culpabilidad.

\section{The guilt and the responsable subjets}

\begin{abstract}
Tomas Cano Campos tries to tie unanimously the concepts: guilt and administrative sanction from the point of view of the Administrative Disciplinary law.

Cano Campos presents in this text the diverse meanings of the concept "guilt / deceit / fault" distinguishable for the context of legislative application, which in addition is clearly differentiated by the author: administrative infractions (personal responsibility and for the fact, subjective responsibility and imputation or guilt in strict sense) and infractions of traffic (responsibility parental before the infractions of underage, responsibility in the suppositions of not identification of the driver, infractions relative to vehicles, subsidiary responsibility not disciplinary, personal imputation or reprochabilidad, minority and psychic disorder and imputation for consumption of alcohol).
\end{abstract}

Key words

Criminal law; Administrative law; Disciplinary Administrative law; Administrative Infractions; Infractions of traffic; Administrative responsibility; Guilt.

* $\quad$ Este trabajo se ha realizado en el marco del Proyecto de Investigación del Ministerio de Ciencia e Innovación "Servicios públicos e infraestructuras en la nueva ordenación del Estado (DER 2009-13764)", del que soy investigador principal en la UCM. 


\section{LOS DISTINTOS SIGNIFICADOS DEL TÉRMINO CULPABILIDAD}

El concepto moderno (constitucional) de sanción está indisolublemente unido al principio de culpabilidad, pues de dicho concepto no solo deriva la exigencia de que la Administración castigue respetando el principio de legalidad sino también el de culpabilidad. El denominado principio de culpabilidad constituye así otra de las exigencias constitucionales a que debe adecuarse el Derecho administrativo sancionador, pero no por una traslación sin más del Derecho penal sino porque sus manifestaciones o exigencias derivan directamente del concepto de sanción propio de un Estado Social y Democrático de Derecho'.

El concepto de culpabilidad es uno de los más ambiguos del Derecho sancionador, pues asume diversos significados generalmente distinguibles por el contexto. La culpabilidad es un principio del esencial del Derecho punitivo, pero también una categoría o elemento esencial del concepto de infracción. En el ámbito administrativo, además, no existe una teoría de la culpabilidad que distinga claramente ambos significados y aclare sus diferencias con el ámbito penal.

\section{La culpabilidad como principio del derecho sancionador}

Como principio del Derecho sancionador o límite al ius puniendi, el concepto de culpabilidad expresa el conjunto de presupuestos o requisitos que permiten "culpar" a alguien, declararle "culpable" y por ello imponerle una sanción. En este sentido se traduce en una serie de exigencias que afectan a los elementos de la teoría de la infracción. En concreto en las siguientes exigencias:

a) La responsabilidad personal y por el hecho. Con la sanción solo se debe castigar al infractor, lo que impide la traslación de la responsabilidad sancionadora a una persona ajena (art. 130 Ley 30/1992, de 30 de noviembre, de Régimen Jurídico de las Administraciones Públicas y del Procedimiento Administrativo Común -LAP-; SSTC 219/1988 y 270/1994; STS de 26 de enero de 1998, Ar. 573). Pero no impide que sujetos distintos al autor material de la infracción se consideran autores de la misma por no haberla evitado pudiendo y debiendo hacerlo o -y esto es más discutible- que respondan de forma solidaria con él del pago de la sanción. Tampoco impide la responsabilidad de las personas jurídicas (art. 30.1 LAP y STC 246/1991, entre otras).

1 La STC 270/1994 señala que el principio de culpabilidad caracteriza al Derecho penal y al Derecho administrativo sancionador propios de un Estado Social y Democrático de Derecho. Lo mismo señala la SAN de 21 de julio de 2004 (Ar. 802 de 2006): “aun sin reconocimiento explícito en la Constitución, el principio de culpabilidad puede inferirse de los principios de legalidad y prohibición de exceso (art. 25.1 CE) o de las exigencias inherentes al Estado de Derecho". En la doctrina, A. Huergo Lora, Las sanciones administrativas, Madrid, lustel, 2007, p. 378, que cita la sentencia del Tribunal Constitucional alemán de 25 de octubre de 1966 donde se destaca ya que una sanción impuesta sin culpabilidad sería un castigo incompatible con el principio del Estado de Derecho. A. Nieto García, Derecho administrativo sancionador, $4^{\text {a }}$ ed., Madrid, 84 Tecnos, 2005 , sin embargo, considera que resulta más realista sostener que la culpabilidad "carece de base 
b) La exigencia de dolo o culpa (responsabilidad subjetiva). El Derecho sancionador sólo puede tratar de impedir las lesiones o puestas en peligro de los bienes jurídicos prohibiendo conductas voluntarias capaces de producir tales resultados de forma dolosa (por estar dirigidas a ello de forma consciente) o imprudentes (por infringir las normas de cuidado presentes en cada sector). Se excluye así la sanción objetiva o por el resultado [STC 76/1990, SSTS de 9 de enero de 1972 (Ar. 876), de 25 de enero de 2006]. El art. 130 LAP no consagra expresamente la responsabilidad subjetiva, pues habla de "simple inobservancia", aunque si se entiende -como es debido para que el precepto sea conforme a la Constitución- que la inobservancia se refiere a las normas de cuidado dicha exigencia estaría implícita en el precepto. La responsabilidad subjetiva la reflejan certeramente, sin embargo, el art. 183.1 de la Ley General Tributaria o el art. 52 de la Ley General de Subvenciones. Como hemos de ver, la diligencia exigible o las reglas de cuidado que han de respetarse están normalmente positivizadas en el ámbito sancionador, de modo que las normas que regulan los distintos sectores no hacen sino normativizar aquella diligencia, establecer cuales son las reglas de cuidado que deben observarse en ese sector, marcando así las fronteras del riego permitido en el mismo.

c) La imputación personal o culpabilidad en sentido estricto. Requiere que la conducta pueda atribuirse o reprocharse a su autor por concurrir en éste las condiciones físicas y psíquicas (en el caso de las personas físicas) que le permiten un acceso o una motivación normal al mensaje de las normas prescriptivas o de conducta, lo que falta cuando no se ha alcanzado cierta edad (que no tiene por qué ser la mayoría de edad), o en los supuestos de enfermedad mental, error de prohibición, miedo insuperable, etc., y que por eso se denominan causas de inimputabilidad.

\section{La culpabilidad como elemento esencial del concepto de infracción administrativa}

La culpabilidad también constituye un concepto dogmático, uno de los elementos esenciales del concepto de infracción, cuyo contenido -más reducido- no coincide con el principio punitivo de culpabilidad ${ }^{2}$. El concepto de infracción se pregunta por los presupuestos o requisitos necesarios para poder imponer a alguien una sanción administrativa. Y la respuesta es esta: ha de sancionarse al sujeto que se ha comportado contraviniendo las normas y de forma culpable. Por ello, siguiendo la definición de delito, se señala que la infracción administrativa es una acción típica, antijurídica y culpable (STS de 23 de febrero de 2000, Ar. 7047). Algunas resoluciones hablan de "conductas típicamente antijurídicas" y culpables (STS de 19 de mayo de

2 El principio de culpabilidad también es utilizado con un sentido más restringido, para referirse únicamente a la exigencia de dolo o culpa en las infracciones administrativas. En tal sentido lo utiliza, por ejemplo, el art. 3 de la Ley $2 / 1998$, de 20 de febrero, de la potestad sancionadora de las Administraciones Públicas de la Comunidad Autónoma del País Vasco (LPSPV). Pero en este caso sería más correcto hablar del principio de responsabilidad subjetiva, en contraposición al principio de responsabilidad objetiva que se critica, constituyendo uno de los requisitos del principio de culpabilidad en sentido amplio. 
1981, Ar. 1976), mientras que otras anteponen la antijuridicidad a la tipicidad y definen la infracción como acción antijurídica, típica y culpable.

Adoptando una concepción bipartita (la infracción consta de dos elementos esenciales), la infracción administrativa se puede definir como una acción antijurídica y personalmente imputable castigada por la ley con una sanción administrativa. Esta concepción parece preferible a la tripartita clásica y dominante. Primero: porque parece razonable sostener que los dos únicos juicios generales de valor que pueden hacerse sobre un comportamiento determinado son el que lo muestra objetivamente como contrario al ordenamiento jurídico (antijuridicidad, entendida como juicio intersubjetivo válido para todos los sujetos) y el que lo atribuye individualmente a su autor (imputabilidad, reprochabilidad o culpabilidad en sentido estricto, entendida como posibilidad de imputar el hecho antijurídico a un sujeto responsable). Segundo: porque la tipicidad más que un elemento independiente de la antijuridicidad (que pueda situarse sistemáticamente antes o después de la misma), constituye, junto a los de acción y ausencia de causas de justificación, uno de sus requisitos. En cualquier caso, se trata de una cuestión que casi no ha sido tratada entre los administrativistas y que continúa totalmente abierta entre los penalistas. Lo importante es que deben concurrir todas esas notas para que se cometa una infracción y, por tanto, se pueda sancionar.

Pues bien, asumiendo la referida postura los elementos esenciales de las infracciones de tráfico, como de las administrativas en general, serían pues la antijuridicidad (sancionadora), que incluye la tipicidad y la ausencia de causas de justificación (estado de necesidad, ejercicio de un derecho, cumplimiento de un deber, etc.), y la culpabilidad o imputación personal.

La culpabilidad o imputabilidad como categoría de la infracción se refiere a la posibilidad de imputar o reprochar personalmente el hecho antijurídico a un sujeto responsable. Se ocupa por ello de las condiciones que determinan que el autor de una conducta antijurídica pueda ser sancionado por resultar el responsable de la misma, por podérsela "reprochar". Es la atribuibilidad individual del hecho antijurídico al sujeto que lo ha realizado. Lo que tiene lugar cuando se puede exigir a dicho sujeto actuar de conformidad con las normas (SSTS de 27 de mayo de 1999, Ar. 4504; de 5 de febrero de 1999, Ar. 1824; STSJ de Asturias de 10 de noviembre de 2000, Ar. 204). Su fundamento reside esencialmente en la normalidad en la recepción del mensaje de la norma, que queda excluida en el caso de los menores de cierta edad, en quienes sufren determinados trastornos o en el error de prohibición y en el estado de necesidad exculpante. En tales casos no se podrá imponer una sanción por impedirlo el principio de culpabilidad, pero sí se podrá exigir responsabilidad patrimonial u obligar a cumplir medidas de restablecimiento de la legalidad vulnerada, pues tales institutos no están sometidos a o condicionados por la exigencia de culpabilidad.

La legislación de tráfico no alude expresamente a tales requisitos, que están 86 implícitos en el concepto mismo de infracción, sino que suele mencionar únicamen- 
te el de la tipicidad: “Las acciones u omisiones contrarias a esta Ley, desarrolladas reglamentariamente en su caso, tendrán el carácter de infracciones administrativas y serán sancionadas en los casos, forma y medida que en ella se determinen" (art. 65.1 LTSV). En los apartados que siguen nos centraremos en el estudio de cada una de las exigencias en que se traduce el principio de culpabilidad y su plasmación en el concreto sector del tráfico. Comenzaremos con la exigencia de dolo o culpa (que, en mi opinión, en la teoría de la infracción administrativa encuentra una ubicación sistemática más adecuada en la antijuridicidad), después analizaremos el principio de personalidad de las sanciones así como los sujetos responsables de las infracciones de tráfico, para concluir nuestro estudio con la imputabibilidad o reprochabilidad y los supuestos más importantes en que puede estar ausente en el sector del tráfico rodado.

\section{LA EXIGENCIA DE DOLO O CULPA. LAS NORMAS DE TRÁFICO COMO POSITIVIZACIÓN DE LAS NORMAS DE DE CUIDADO (DILIGENCIA EXIGIBLE) EN EL SECTOR}

Las infracciones de tráfico, como todas las demás, solo son tales si se cometen con dolo o de forma imprudente. Aunque la CE no contiene una afirmación expresa de la exigencia de dolo o culpa, tanto la doctrina casi unánime como la jurisprudencia coinciden hoy en señalar que sólo se puede imponer una sanción administrativa en presencia de un comportamiento doloso o negligente.

EI TC se pronunció de forma clara sobre el tema en su sentencia 76/1990, en la que resolvió un recurso de inconstitucionalidad y diversas cuestiones planteadas por la entonces Audiencia Territorial de Valencia y por el Tribunal Supremo contra la Ley 10/1985 de modificación de la Ley General Tributaria, afirmando que la exclusión en ésta de cualquier adjetivación de las acciones u omisiones constitutivas de infracción administrativa [como también ocurre en materia de tráfico],

"no puede llevar a la errónea conclusión de que se haya suprimido en la configura-
ción del ilícito tributario el elemento subjetivo de la culpabilidad para sustituirlo por
un sistema de responsabilidad objetiva o sin culpa. En la medida en que la sanción
de las infracciones tributarias es una de las manifestaciones del ius puniendi del Es-
tado, tal resultado resultaría inadmisible en nuestro ordenamiento [...]. Sigue ri-
giendo el principio de culpabilidad (por dolo, culpa o negligencia grave y culpa o
negligencia leve o simple negligencia), principio que excluye la imposición de san-
ciones por el mero resultadoy sinatender a la conducta diligente del contribuyente"’.

EI TS, por su parte, también señaló ya en su conocida sentencia de 9 de enero de 1972 (Ar. 876) que "es necesaria la concurrencia del elemento subjetivo de culpabilidad para que un hecho antijurídico pueda sancionarse y ello tanto en la esfera del

3 En el mismo sentido STC 246/1991. 
derecho penal como en el campo del derecho administrativo sancionador"4. En la sentencia de 25 de enero de 2006 (recurso núm. 7396/2001), entiende que el propio artículo 130.1 de la Ley 30/1992 consagra la exigencia de dolo o culpa en las infracciones administrativas, pues la alusión que dicho precepto hace a la "simple inobservancia” en modo alguno puede ser entendido como la admisión en el Derecho administrativo sancionador de una especie de responsabilidad objetiva.

La justificación de dicha exigencia se ha visto en el principio del Estado de Derecho, en el valor de la dignidad humana, en el propio art. 25.1 CE, en la presunción de inocencia del art. 24.2 CE o en el hecho de constituir un principio estructural básico del Derecho sancionador. La STS de 23 de enero de 1990 (recurso 5397/1992) señala que "el fundamento del principio de culpabilidad puede inferirse de los principios de legalidad y prohibición del exceso (artículo 25 CE) o de las exigencias inherentes al Estado de Derecho".

El fundamento, en mi opinión, reside en que el Derecho sólo puede prohibir comportamientos voluntarios dolosos o imprudentes, ya que para el Derecho sancionador sólo pueden ser relevantes las conductas en que concurran tales notas ${ }^{5}$. El Derecho administrativo sancionador, al igual que el Penal, sólo puede intentar legítimamente impedir las lesiones o puestas en peligro de los bienes jurídicos prohibiendo conductas voluntarias capaces de producir tales resultados de forma dolosa, por estar dirigidas conscientemente a lesionar tales bienes, o imprudentes, por lesionar tales bienes infringiendo las normas de cuidado exigibles en el sector, superando así el umbral del riesgo permitido. E. Gimbernat lo ha explicado así en el ámbito penal con argumentos también válidos para nosotros: "como el legislador lo único que puede motivar son conductas correctas, ahí está el límite de lo que racionalmente puede prohibir: si el sujeto se comporta cuidadosamente (lo único que está en su mano hacer) y, no obs-

4 La jurisprudencia desde entonces, sobre todo tras la CE, es muy abundante: SSTS 30 de junio de 1988 (Ar. 5180), 10 de febrero de 1989 (Ar. 2461), 13 de octubre de 1989 (Ar. 8386), 21 de febrero de 1990 (Ar. 7495), 9 de enero de 1991 (Ar. 3447), 5 de febrero de 1992 (Ar. 2300), 30 de noviembre de 1993 (Ar. 1230), 9 de julio de 1994 (Ar. 5590), 14 de julio de 1998 (Ar. 7607), 5 de febrero de 1999 (Ar. 1824), 3 de abril de 2000 (Ar. 2579), 22 de noviembre de 2004 (Ar. 20 de 2005), 18 de octubre de 2006 (Ar. 6679), etc.

5 Como ha señalado G. Quintero Olivares, "La autotutela, los límites al poder sancionador de la Administración Pública y los principios inspiradores del Derecho penal”, en Revista de Administración Pública núm. 126, 1991, el dolo y la culpa no son privativos del Derecho Penal, pues "dolosidad y culposidad de la conducta humana son conceptos categóricamente válidos para la totalidad del Ordenamiento Jurídico, aunque hayan sido aportados por el Derecho Penal”, por ello, la razón "por la que ha de concurrir dolo o culpa en la infracción administrativa no reside en el parentesco con el derecho penal únicamente” (pp. 264-265). Para E. Bacigalupo Zapater, “¿Tienen rango constitucional las consecuencias del principio de legalidad?”, en La Ley, 1982, pp. 936 y ss., la exigencia de dolo o culpa deriva del derecho a la libertad y seguridad del art. $17 \mathrm{CE}$, pues "nadie es libre ni goza de seguridad si el Estado puede aplicarle penas por hechos u omisiones inevitables, es decir, que no sean consecuencia de su acción voluntaria evitable". Y en opinión de A. De Palma del Teso, El principio de culpabilidad en el Derecho administrativo sancionador, Madrid, Tecnos, 1996, el fundamento de la exigencia de dolo o culpa en las infracciones administrativas reside en la función de prevención general y especial de las sanciones, que se vería desvirtuada si se impusiesen a quienes han actuado sin dolo o culpa (p. 44). Vid. también, de la misma autora, "Principio de culpabilidad: definición y aplicación”, en B. Lozano Cutanda (dir.), Diccionario de sanciones administrativas, Madrid, lustel, 2010, págs. 702 y ss. 
tante, lesiona fortuitamente un bien jurídico (lo que cae ya fuera de su control), ello no puede constituir una conducta prohibida, pues lo que el Derecho quería -y podíaproducir se ha producido: que se actuase diligentemente al ejecutar la acción" ${ }^{\text {. Sólo }}$ las conductas cometidas con dolo o negligencia se pueden reputar antijurídicas y calificar como infracción administrativa, pues sólo tales comportamientos pueden ser objeto de la norma sancionadora primaria concebida como imperativo capaz de incidir en o motivar la conducta de los sujetos (norma imperativa o de conducta). Por el contrario, los procesos puramente fortuitos, inevitables para el sujeto, o aquellos que no revisten el carácter de acción, en la medida en que no pueden ser condicionados por la norma, carece de sentido conminarlos con una sanción. De este modo parece claro que las normas sancionadoras no pueden tener por objeto simples estados o procesos de la naturaleza, los cuales pueden ser valorados pero no prohibidos ya que no entran dentro de lo que se puede determinar, es decir, evitar a través de la incidencia de las normas`. O, ¿es que acaso puede prohibirnos el Derecho “saltarnos un semáforo", por ejemplo, cuando ha habido un fallo mecánico en nuestro vehículo que impide su detención o cuando invadimos el carril contrario debido al hielo de la calzada?

En un Estado social y democrático de Derecho sólo es posible, necesario y, por tanto, legítimo prohibir bajo la amenaza de sanción conductas dolosas o imprudentes. En dicha cláusula radicaría, cuando menos, el engarce constitucional de la exigencia de dolo o culpa, como también en la interdicción de la arbitrariedad de los poderes públicos (art. 9.1 CE), pues un legislador que prohíbe bajo amenaza de sanción lo no que no puede prohibirse y lo que no es necesario prohibir, porque no se puede evitar, es un legislador arbitrario y la ley que plasme una prohibición tal es una norma contraria a la Constitución ${ }^{8}$.

Algunas normas administrativas, como se ha adelantado, comienzan ya a consagrar de forma expresa la necesidad de dolo o culpa de las infracciones administrativas. Tal es el caso de la Ley General Tributaria de 2003: "Son infracciones tributarias las acciones u omisiones dolosas o culposas con cualquier grado de negligencia que estén tipificadas y sancionadas como tales en esta u otra ley" (art. 183.1). Otras normas, como la reciente Ley 38/2003, de 17 de noviembre, General de Subvenciones, habla de "simple negligencia" (art. 52). La LPSPV reconduce la simple inobservancia de que habla la LAP a la negligencia: "No hay sanción sin dolo o imprudencia, incluida en esta última la simple inobservancia” (art. 3).

La ausencia de una mención expresa al dolo o la culpa en el art. 130.1 cuando dispone que "sólo podrán ser sancionadas por hechos constitutivos de infracción administrativa las personas físicas y jurídicas que resulten responsables de los mismos aún a título de simple inobservancia", no permite concluir que se esté consagrando en

6 E. Gimbernat Ordeig, Estudios de Derecho penal, $3^{\text {a }}$ ed., Madrid, Tecnos, 1990, p. 180.

7 J. M. Silva Sánchez, Aproximación al Derecho penal contemporáneo, $2^{\mathrm{a}}$ ed., Montevideo-Buenos Aires, editorial B de F, 2010, p. 541.

8 Vid. T. R. Fernández Rodríguez, De la arbitrariedad del legislador. Una crítica de la jurisprudencia constitucional, Madrid, Civitas, 1998. 
el Derecho administrativo sancionador la denominada responsabilidad objetiva o por el resultado9. La constitucionalidad del precepto (pues la exigencia de dolo o culpa tiene, como acabamos de ver, anclaje en la propia $(E)$ se puede salvar entendiendo que la inobservancia a que alude no es el puro incumplimiento, el incumplimiento formal de una norma prescriptiva, o que consagra una forma de negligencia (la culpa levísima), sino considerando que el incumplimiento o inobservancia a que se refiere el precepto es el de la norma de cuidado exigible en cada caso, con lo cual estaría consagrando la necesidad de que cuando menos concurra culpa, o la falta del cuidado debido, en el autor de la infracción ${ }^{10}$.

En el Derecho administrativo sancionador, a diferencia del Derecho penal, lo normal será la falta del cuidado debido, esto es, la comisión de las infracciones por culpa o negligencia ${ }^{11}$. Esto no quiere decir que no haya tipos exclusivamente dolosos. Algunas infracciones de tráfico solo se puede cometer dolosamente: por ejemplo, la negativa a someterse a las pruebas de alcoholemia o a exhibir el permiso de conducción. Las demás también se pueden cometer dolosamente si el comportamiento se realiza con conocimiento (o con conocimiento y voluntad, en función de la teoría del dolo que se mantenga): conducir un vehículo sabiendo que se carece de la autorización administrativa correspondiente, circular con un vehículo del que se sabe no ha pasado la

9 En Italia y Alemania se ha consagrado de forma expresa la exigencia de dolo o culpa en la infracciones administrativas. El art. 3.1 de la Ley italiana de despenalización establece que "en las infracciones que lleven aparejada una sanción administrativa, cada uno es responsable de su propia acción u omisión, consciente o voluntaria, sea dolosa o culposa", mientras que el art. 10 de la Ley alemana de contravenciones dispone que "sólo puede ser castigado como infracción administrativa un hecho doloso, a menos que una Ley expresamente prevea una multa para un hecho culposo".

10 Para A. Nieto García, Derecho..., cit., el art. 130 de la LAP se adecuaría a la CE si se entiende que "no está hablando de autores sino de responsables", para los que no rige la exigencia de dolo o culpa (p. 392). Como es sabido, este autor distingue en el ámbito del Derecho administrativo sancionador entre autoría y culpabilidad. El infractor -dice- es el autor de la infracción y a quien se aplica la regla de la exigencia de dolo o culpa, pero junto al autor se encuentra el responsable que es quien debe soportar las consecuencias de la infracción (sanción y, en su caso, reparación) y a quien no se exige dolo o culpa. Ahora bien, además de lo discutible que resulta entender -como el mismo autor reconoce- que el art. 130.1 de la LAP no esté aludiendo a los autores sino a los responsables (el art. 130.3 se refiere claramente a los autores), no se explica el fundamento y la finalidad de esa disociación entre autoría y responsabilidad en el ámbito sancionador. La función de las normas sancionadoras no es otra, como el propio autor explica en otras partes de su excelente libro, que impedir que se realicen determinados comportamientos que pueden poner en peligro o lesionar determinados bienes jurídicos. La amenaza de sanción es un estímulo dirigido al destinatario de la norma para que no realice tales comportamientos. ¿Cómo puede entonces motivar una norma sancionadora a un autor no responsable o a un responsable no autor?, esto es, a una persona que sabe que aunque realice el comportamiento prohibido no va a responder (no va a ser sancionado por ello) o a una persona que sabe que, haga lo que haga, actúe con toda la diligencia exigible o no, va a ser sancionado. Esta discutible tesis tampoco explica el fundamento de una responsabilidad en el ámbito sancionador ex lege y objetiva. ¿Puede hacer tal cosa el legislador sin incurrir en arbitrariedad? El problema de la responsabilidad de las personas jurídicas, que es el que subyace en todo este tema, puede ser resuelto de otra forma, sin necesidad de escindir autoría y responsabilidad. Para A. de Palma, El principio..., cit., que también critica la tesis de Nieto, la interpretación realizada por el TC en la sentencia 76/1990 es trasladable al art. 130.1 de la LAP, por lo que la simple inobservancia a que alude consagra la denominada "culpa levísima” que supone la ausencia de "la diligencia exigible al hombre más cuidadoso" (pp. 134 y ss.).

$11 \quad$ El art. 12 CP dispone que: “Las acciones u omisiones imprudentes sólo se castigarán cuando expresamente lo disponga la Ley". 
ITV, conducir un vehículo sabiendo que su carga está mal acondicionada, etc. El que lo normal en el sector sea la comisión por imprudencia, tampoco quiere decir que la comisión dolosa revista la misma gravedad y por tanto comporte la misma reacción punitiva que la imprudente cuando ambas sean posibles, pues el dolo (intencionalidad) opera como agravante de la sanción (art. 131.3 LAP). Lo que se quiere significar es que las infracciones administrativas, y especialmente las de tráfico, constituyen por lo general una infracción de la norma de cuidado. Norma de cuidado que normalmente está positivizada, residiendo aquí muchos de los equívocos en la materia que conducen a que algunos nieguen la exigencia de dolo o culpa en las infracciones administrativas. La normativa reguladora del tráfico, como la normativa de otros muchos sectores, no es más que la normativización de la diligencia exigible en el sector, la positivización de las normas de cuidado que deben seguirse en el mismo y que marcan las fronteras mismas del riesgo permitido y, por tanto, del injusto administrativo.

Las infracciones de tráfico son, por lo general, infracciones de peligro abstracto y hasta presunto, estadístico o total ${ }^{12}$. Se trata de tipos de mera actividad que no requieren un resultado separable espacio-temporalmente de la acción (el resultado sería la realización de la propia conducta descrita en el tipo: conducir superando los límites de velocidad o las tasas de alcohol reglamentarias, utilizando el móvil, sin cinturón de seguridad, etc. $)^{13}$. La simple realización del tipo supone, salvo que concurra una causa de justificación (estado de necesidad, cumplimiento de un deber) o de exculpación (trastorno mental, minoría de edad), la comisión de la infracción sin necesidad de analizar si dicho comportamiento es negligente desde el baremo habitual de la diligencia del hombre medio (del conductor diligente o responsable en nuestro caso), pues la diligencia exigible, las fronteras de la negligencia, las marca el propio tipo al positivizar el cuidado debido.

12 Como señala J. M. Silva Sánchez, La expansión del Derecho penal. Aspectos de la política criminal en las sociedades postindustriales, $2^{\text {a }}$ ed., Madrid, Civitas, 2001, pp. 126 y ss., el Derecho administrativo sancionador persigue reforzar un determinado modelo de gestión sectorial, razón por la cual se centra en la globalidad del modelo, en el sector en su integridad, de modo que lo determinante para él es la visión macrosocial, las "grandes cifras", el "problema estructural” o "sistémico", y por eso tipifica infracciones y establece sanciones desde enfoques generales, atiende a consideraciones de afectación general”. Por ello, continúa, el Derecho administrativo sancionador, no requiere que una conducta, en sí misma considerada, sea relevantemente perturbadora de un bien jurídico, pues no realiza un análisis de la lesividad o peligrosidad en el caso concreto, sino que se conforma con que el género de conductas tipificadas como tales represente, en términos estadísticos, un peligro para el buen orden del sector de actividad de que se trate, pero no un peligro concreto o incluso abstracto (entendido como peligro realmente existente, constatable en la conducta en virtud de un juicio ex ante), sino un peligro presunto, estadístico o global. El Derecho administrativo sancionador es así el derecho del daño cumulativo, del daño derivado de la repetición, lo que en general exime de una valoración del hecho específico, requiriendo sólo una valoración acerca de cuál sería la trascendencia global de un determinado género de conductas si éstas se estimaran lícitas o no sancionables. Como señala el mismo autor, y ello es muy pertinente en el sector del tráfico, la pregunta clave es la siguiente: ¿Qué pasaría si todos los intervinientes en este sector de actividad realizaran la conducta $\mathrm{X}$ cuando existe, además, una seria probabilidad de que muchos de ellos lo hagan, de ser estimada lícita? Pregunta que adquiere todo su sentido desde perspectivas de gestión de un determinado sector (el urbanismo, el consumo, el medio ambiente, el propio tráfico rodado, etc.)

13 Lo que ocurre, como señala A. Huergo Lora, Las sanciones..., cit., p. 387, en la inmensa mayoría de las infracciones administrativas. 
Esto es lo que ocurre en la mayor parte de las infracciones administrativas, tal y como adelantó ya $\mathrm{O}$. Mayer y ha desarrollado entre nosotros $\mathrm{M}$. Rebollo y, más recientemente, A. Huergo ${ }^{14}$. La idea también está presente en el propio Derecho penal, explicando así el surgimiento de los delitos de peligro en los que se castiga sin necesidad de resultado ${ }^{15}$. Y otro tanto ocurre en el Derecho de daños, donde el concepto de diligencia, que es un concepto normativo y no psicológico, también se ha positivizado en numerosos sectores (la propia circulación de vehículos, estatutos sobre la seguridad e higiene en el trabajo, prescripciones de la industria alimentaria o de la construcción, etc. $)^{16}$.

En el sector del tráfico dicha positivización es clara y obedece a dos razones esenciales. Primera: como en dicho ámbito resultan necesarias decisiones masivamente semejantes, es necesaria una estandarización del comportamiento de los participantes, pues si no fuese así ¿a qué comportamiento del otro ha de ajustarse uno? ${ }^{17}$. Segunda: la experiencia acumulada y los estudios realizados permiten una mayor "tipificación" de las normas de cuidado, de modo que la fuente del deber de cuidado ya

14 O. Mayer, Derecho Administrativo alemán, Buenos Aires, Depalma, 1949: “No hay pena policial sin culpa [... . Pero la culpa puede consistir en la simple negligencia en que incurre el individuo al no hacer lo necesario para cumplir con su deber [... P Por esta razón bastará, en efecto, el simple hecho exterior de no haber logrado el fin del deber, de no haber evitado la perturbación, de no haber hecho lo necesario para impedirlo, para que haya violación punible del deber", de este modo "quien no puede mantener absolutamente cerrado su patio, está ya en falta por el hecho mismo de dejar correr libremente a su animal en dicho patio; quien no puede dominar a su caballo está en falta frente al buen orden de la cosa pública desde el momento en que sube a la silla de montar", por tanto "si el hecho exterior de una conducta contraria a la policía basta para comprobar la culpa, es preciso, para eludir el castigo, demostrar lo contrario mediante causas especiales apropiadas para descartar la culpa. Pero si se reconocen causas de ese género, esto demuestra claramente que la pena policial supone su culpa" (pp. 103-106). M. Rebollo Puig, Potestad sancionadora, alimentación y salud pública, Madrid, MAP, 1990: las infracciones de mera conducta "lo que en verdad tipifican es la imprudencia”, por eso la previsibilidad y la evitabilidad (que se exigen para la imprudencia) hay que referirlas a la acción" (pp. 635-637 y 767). A. Huergo Lora, Las sanciones..., cit., pp. 388-394 ha recordado tales precedentes y ha señalado en el mismo sentido que cuando el legislador habla en el art. 130.1 de mera inobservancia de las normas que establecen prohibiciones y obligaciones con una finalidad preventiva como título suficiente para la responsabilidad no está excluyendo la culpabilidad, sino que lo que quiere decir es que los destinatarios de tales normas tienen el deber de conocerlas y cumplirlas, pues de otro modo actúan con negligencia, "el legislador está fijando el nivel de diligencia exigible, está afirmando que quien incumple esa norma actúa por ello mismo culposamente, en lugar de remitir la fijación de ese nivel de diligencia a los Tribunales a través de criterios estimativos como la diligencia de un hombre medio" (p. 389).

15 Como ha señalado S. Mir Puig, Derecho Penal. Parte General, $8^{a}$ ed., Barcelona, Repertor, 2008, p. 295, recurriendo precisamente al sector que nos ocupa, “cuando, como sucede en el tráfico rodado, el peligro para bienes jurídicos importantes aumenta tan considerablemente, y por otra parte la experiencia permite tipificar mejor los límites de la norma de cuidado, por lo que se puede juzgar con cierta seguridad la imprudencia de una acción por sí misma, la necesidad de efectiva causación de un resultado disminuye. Así nacen los delitos de peligro”. En parecidos términos, F. Muñoz Conde y M. García Arán, Derecho Penal. Parte General, $4^{\mathrm{a}}$ ed., Valencia, Tirant lo Blanch, 2000, p. 324: "en algunas ocasiones las reglas de cuidado que deben observarse vienen descritas en preceptos de normas administrativas (el Código de la Circulación), cuya inobservancia constituye generalmente una imprudencia".

16 L. Diez Picazo, Derecho de Daños, Madrid, Civitas, 2000, pp. 359-360, quien señala que "es evidente que cuando un daño se ha causado por no haber cumplido las exigencias legales o reglamentarias establecidas en orden a la previsión y prevención o evitación de los daños, la conducta del sujeto es negligente siempre que el fin de protección de dichas normas coincida con el daño producido" (p. 358).

17 G. Jakobs, Derecho Penal. Parte general. Fundamentos y teoría de la imputación, $2^{\mathrm{a}}$ ed., Madrid, Marcial Pons, 2001, pp. 210-211 
no es el hombre diligente (la diligencia del hombre medio) sino la propia normativa reguladora del tráfico. Las normas de tráfico son así, en su inmensa mayoría, normas de cuidado normativamente definidas a partir de los conocimientos empíricos sobre las causas más frecuentes de los accidentes (o del daño o puesta en peligro de otros bienes jurídicos), constituyendo en su mayor parte la plasmación normativa de respuestas anticipatorias de evitación del riesgo de accidentes ${ }^{18}$. El legislador tipifica así el riesgo permitido, el peligro jurídicamente relevante que no debe crearse, el cual constituye el tope máximo de la norma de cuidado y no opera como una causa de justificación, sino que excluye la propia tipicidad ${ }^{19}$. Por ello, tales normas marcan o delimitan la barrera a partir de cuya superación comienza la imprudencia ${ }^{20}$. Es la propia norma la que marca ya el cuidado debido, la diligencia exigible (o, si se quiere el riesgo permitido) obligando a no realizar el tipo por ella descrito. Por eso la simple realización del tipo de forma no justificada o exculpante supone "automáticamente" la comisión de la infracción. No es preciso, pues, un actuar negligente en la infracción del deber de cuidado fijado legalmente por la norma, como parecen apuntar algunos $^{21}$. La simple infracción de tal deber previsto en la propia norma constituye ya un actuar imprudente, porque la propia norma marca el umbral de la prudencia exigible.

En cualquier caso, en el ámbito penal, en la imprudencia, junto a la infracción de la norma de cuidado o la creación de un riesgo no permitido, se exige la cognoscibilidad y la evitabilidad (o previsibilidad) del resultado (pues normalmente se trata de delitos de este tipo), pero en las infracciones de actividad, que son la inmensa mayoría de las infracciones administrativas y de las de tráfico, tales requisitos no se pueden referir al resultado que no es un elemento del tipo, sino a la propia acción. Por consiguiente habrá imprudencia cuando se incumpla el deber de evitar acciones típicas cognoscibles en el supuesto de que sean antijurídicas ${ }^{22}$. Si lo que hay no es cognosci-

18 G. Benlloch Petit, "La eficacia de las sanciones penales y administrativas en la lucha contra la siniestralidad viaria”, en Tráfico y Seguridad Vial núm. 73, 2005, pp. 8-9.

19 C. Roxin, Derecho Penal Parte General, Tomo I (traducción y notas de D. M. Luzón Peña, M. Díaz y García Conlledo y J. de Vicente Remesal), Madrid, Civitas, 2003, p. 998; G. Jakobs, Derecho Penal..., cit., p. 245; S. Mir Puig, Derecho penal..., cit., p. 291.

20 C. Roxin, Derecho Penal..., cit., p. 998.

21 Por ejemplo A. de Palma del teso, "La culpabilidad”, en Justicia Administrativa núm. extraordinario de 2001, p. 35, cuando señala que: "actúa de forma culposa o imprudente la persona que, al desatender un deber legal de cuidado, no se comporta con la diligencia que le es exigible y realiza (de forma no dolosa o intencionada) la conducta tipificada como infracción, siendo tal hecho previsible y evitable. Por lo tanto, la culpa o imprudencia supone la inobservancia de la diligencia exigible. La infracción de una norma de cuidado mediante un actuar negligente, descuidado, imprevisor, que lleva a la persona a realizar la conducta constitutiva de la infracción" (Las cursivas son mías). Si estoy en lo cierto y no interpreto mal lo que señala la autora, ello supondría analizar, por ejemplo, si ha actuado con la diligencia debida (utilizando el baremo del hombre medio) quien ha incumplido la obligación de conducir con las autorizaciones y el resto de documentos exigibles, o con las puertas del vehículo cerradas, o respetando las señales de tráfico, etc.. Pero, como se señala en el texto, el simple incumplimiento de tales obligaciones supone ya una infracción de la diligencia debida.

22 G. Jakobs, Derecho penal..., cit., p. 381, para quien la "imprudencia es, pues, aquella forma de la evitabilidad en la que falta el conocimiento actual de lo que ha de evitarse” (p. 382). En opinión de A. Huergo Lora, Las sanciones..., cit., "cuando la norma dispone que el simple incumplimiento de un deber o prohibición constituye una infracción administrativa, no es que esté aplicando el principio de responsabilidad 
bilidad sino conocimiento (o conocimiento y voluntad, en función de la teoría del dolo que se siga) en la realización de la acción típica, el comportamiento no será imprudente sino doloso. Así, quien sabe que conduce sobrepasando los límites de velocidad o sin la documentación exigida comete dolosamente la infracción correspondiente, pues la imprudencia se caracteriza negativamente por faltar en ella el conocimiento de la realización del tipo ${ }^{23}$.

Parece pues evidente que el Derecho administrativo sancionador ni prescinde ni puede prescindir del dolo y de la culpa o negligencia, salvo que se quiera utilizar como un instrumento que en vez de una función punitiva cumpla una finalidad resarcitoria o, lo que es peor, puramente recaudatoria. Quien obra cumpliendo las normas de cuidado positivizadas no puede ser sancionado, pues al no crear riesgos prohibidos no está realizando ningún comportamiento típico. El Derecho administrativo sancionador no puede obligar a nadie más allá de la observancia del cuidado exigible, pues en otro caso estará prohibiendo y sancionando lo que se produce o tiene lugar de forma fortuita o por fuerza mayor.

\section{EL PRINCIPIO DE RESPONSABILIDAD PERSONAL Y POR EL HECHO}

\section{Contenido y fundamento del principio}

De conformidad con el principio de personalidad de las sanciones o de responsabilidad personal por hechos propios que rige en el Derecho punitivo, las sanciones administrativas deben dirigirse directamente contra la persona que ha cometido la infracción, pues solo así pueden servir de reproche por la conducta de su autor y cumplir, mediante la causación del daño o perjuicio en que consisten, la finalidad de prevención especial y general a que están orientadas. Además, las sanciones sólo pueden imponerse por hechos o conductas, no por la personalidad o la forma de ser del autor de la infracción.

El principio de responsabilidad personal y por el hecho o acción está consagrado expresamente en nuestro Derecho positivo y ha sido destacado en varias ocasiones por la jurisprudencia. El art. 130 LAP (aunque reconoce la responsabilidad solidaria y subsidiaria) comienza señalando que "sólo podrán ser sancionadas por hechos constitutivos de infracción administrativa ... las personas que resulten responsables de los mismos", y por eso se tiene en cuenta como criterio de graduación de las sanciones la existencia en el infractor de "intencionalidad o reiteración", la reincidencia (art. 131.3 LAP) o "los antecedentes del infractor y su condición de reincidente” (art. 68 LTSV). En la jurispru-

\footnotetext{
objetiva, sino que está disponiendo que en esa actividad se exige un nivel de diligencia que incluye el conocimiento y el cumplimiento de esa prohibición" (p. 391).

23 G. Jakobs, Derecho penal..., cit., p. 382, quien precisa que "tanto el dolo como la imprudencia son formas de la evitabilidad; ambos están determinados por la congnoscibilidad de la realización del tipo; 94 en el dolo, la cognoscibilidad evoluciona a conocimiento, en la imprudencia no. Si en el proceso no se logra demostrar el conocimiento, pero sí la cognoscibilidad, habrá que condenar por imprudencia”.
} 
dencia, entre otras muchas, han destacado este principio las SSTC 219/1988 y 270/1994 o las SSTS de 26 de enero de 1988 (Ar. 573) y de 27 de marzo de 1998 (Ar. 3415).

El principio de personalidad de las sanciones también implica que cuando la infracción haya sido cometida por varias personas, la sanción prevista sea impuesta a todas y cada una de ellas, pues la finalidad de las sanciones no es reparatoria sino preventiva (mediante el reproche o castigo en que consisten). Por eso no tiene un fácil acomodo en el ámbito sancionador la responsabilidad solidaria y subsidiaria, cuyo campo propio es el Derecho de obligaciones y la responsabilidad $\mathrm{civil}^{24}$.

En el plano normativo, la Ley de la potestad sancionadora del País Vasco (LPSPV) descarta la responsabilidad solidaria o subsidiaria del ámbito punitivo por considerar que "estas figuras, propias del Derecho Civil, no pueden aplicarse en lo tocante a la sanción propiamente dicha so pena de herir de muerte el principio de responsabilidad personal, que es principio definidor de lo punitivo (otra cosa es que se apliquen las responsabilidades civiles o similares que se deriven de la infracción...)". Dicha Ley, salva las exigencias del art. 130.3 LAP (responsabilidad de todos los que siendo destinatarios de una obligación la incumplan y responsabilidad de quienes incumplan la obligación legal de prevenir la infracción cometida por otro), en el primer caso, a través de la coautoría y, en el segundo, mediante una forma de participación equivalente a la autoría, institutos ambos compatibles con el principio de culpabilidad en su manifestación de personalidad de las sanciones (Exposición de Motivos de la Ley).

El fundamento del principio de personalidad de las sanciones reside en la propia función de las sanciones, pues solo si éstas se imponen a los que cometen o participan en la comisión de las infracciones tendrá sentido realizar un reproche y castigar al autor de un hecho con una finalidad preventiva (general y especial). Por eso la responsabilidad sancionadora se extingue con la muerte del infractor o las infracciones y las sanciones tienen un plazo de prescripción: en el primer caso porque ya no hay un sujeto al que reprochar nada, en el segundo porque no tiene sentido castigar o reprochar un comportamiento previo pasado cierto tiempo.

24 A. Huergo Lora, Las sanciones..., cit., pp. 395 y ss. La solidaridad, dice este autor, es "abiertamente contraria al principio de culpabilidad porque, como he dicho, obliga a un sujeto a pagar por la infracción que ha cometido él y por la que han cometido otros. Además, se trata de un sinsentido dogmático porque, si la solidaridad sirve para proteger los intereses del acreedor, aquí no se produce ese resultado. El fin de la sanción es, como sabemos, la prevención general y especial. Ese fin se frustra respecto al infractor que no abona su sanción, y esa frustración no desaparace por el hecho de que otro infractor pague su sanción doble, porque se trata de un fin estrictamente personal [... ] La responsabilidad subsidiaria también tiene un fundamento y un alcance distintos en materia sancionadora y en la responsabilidad civil. El principio de culpabilidad impide sancionar a un sujeto por una conducta imputable a otro respecto del que carece de poder. El hecho de que el primero se enriquezca de alguna manera con la actuación del segundo puede justificar la responsabilidad civil, pero no la sancionadora. De ahí que el garante se exima de responsabilidad sancionadora (no de la civil, sin embargo, en todos los casos) si prueba que cumplió adecuadamente su deber de vigilancia, educación, etc., algo que el artículo 130.3 LPC no reconoce adecuadamente" (pp. 398-399). Vid. también M. J. Gallardo Castillo, Los principios de la potestad sancionadora. Teoría y práctica, Madrid, lustel, 2008, p. 198. En la jurisprudencia pueden destacarse la STS de 30 de septiembre de 1997 (recurso de casación 6584/1993), la STJ de Valencia de 6 de marzo de 2002, cuyas referencias tomo de ésta última autora. 
De conformidad con el referido principio de personalidad, el art. 69.1 de la LTSV dispone que la responsabilidad por las infracciones a lo dispuesto en dicha Ley "recaerá directamente en el autor del hecho en que consista la infracción". El autor es quien realiza el hecho típico, es decir, el comportamiento activo u omisivo en que consiste la parte objetiva de cada tipo infractor. Por eso, y sin perjuicio de lo que se dirá más adelante, habrá que acudir al tipo de cada infracción para determinar quién es el autor y, por tanto, el sujeto responsable.

\section{Los distintos autores de las infracciones de tráfico según el tipo}

En función de los distintos tipos, podrán ser autores de las infracciones de tráfico los siguientes sujetos:

a) En unos casos podrá ser autor cualquier persona: por ejemplo, los sujetos que realicen obras o instalaciones, coloquen contenedores o mobiliario urbano sin autorización previa del titular de la vía, quienes arrojen, depositen o abandonen en la vía objetos o materiales que puedan entorpecer la libre circulación, parada o estacionamiento, o quienes hayan creado sobre la vía algún obstáculo y no lo hagan desaparecer lo antes posible adoptando entretanto las medidas necesarias para que pueda ser advertido por los usuarios (art. 10 LTSV).

b) En otros supuestos serán autores los usuarios de la vía, por ejemplo cuando incumplan la obligación, prevista en el art. 9 LTSV, de comportarse de forma que no entorpezcan indebidamente la circulación, ni causen peligro, perjuicios o molestias innecesarias a las personas, o daños a los bienes, o cuando se vean implicados en un accidente, lo presencien o tengan noticia de él y no auxilien o soliciten auxilio para atender a las víctimas si las hubiere (art. 51 LTSV).

c) En la mayoría de los casos son autores los conductores de los vehículos, por ser a ellos a quienes se dirigen la mayor parte de las normas de tráfico: "los conductores deberán estar en todo momento en condiciones de controlar sus vehículos", "queda prohibido conducir utilizando cascos...", "queda prohibido circular con menores de doce años como pasajeros de ciclomotores o motocicletas", "se prohíbe circular por las autopistas y autovías con vehículos de tracción animal, bicicletas, ciclomotores...", "se prohíbe circular hacia atrás, salvo en los casos en que no sea posible marchar hacia delante ni cambiar de dirección...", "queda prohibido estacionar...", (arts. 11 y ss. LTSV).

d) Pero también pueden ser autores los ocupantes de los vehículos, por ejemplo cuando arrojan a la vía o a sus inmediaciones cualquier objeto que pueda dar lugar a la producción de incendios o poner en peligro la seguridad vial (art. 10.4 LTSV), o 96 LTSV). 
e) Pueden ser autores también los mismos peatones, por ejemplo, cuando transitan por las autovías o cuando no lo hacen por la izquierda en el resto de vías interurbanas, o cuando fuera de poblado, "entre el ocaso y la salida del sol o en condiciones meteorológicas o ambientales que disminuyan sensiblemente la visibilidad”, no vayan provistos de un elemento luminoso o retrorreflectante homologado (arts. 49 LTSV y 121 y ss. del Reglamento General de Circulación).

f) También pueden ser autores los propietarios o los encargados de custodiar a los animales de tiro, carga, silla o las cabezas de ganado aisladas, en manada o en rebaño (arts. 50 LTSV y 126 y ss. RGCir).

g) Pueden serlo igualmente los titulares de los vehículos o sus arrendatarios, por ejemplo, por no mantener a los vehículos en las condiciones legales y reglamentariamente establecidas, sometiéndolos a los reconocimientos e inspecciones que correspondan e impidiendo que sean conducidos por quienes nunca hubieren obtenido el permiso o la licencia de conducción correspondiente (art. 9.3 LTSV), o por no facilitar a la Administración la identificación del conductor del vehículo en el momento de ser cometida una infracción (art. 9.bis LTSV).

h) Y también pueden ser autores los titulares de las autoescuelas y de los centros de reconocimiento de conductores, y el personal de tales centros (directivo, docente, facultativo, administrativo, etc.) en la medida en que son destinatarios de numerosas normas que establecen mandatos y prohibiciones, contenidas en los Reglamentos que regulan tales centros.

Junto a la referida regla, manifestación del principio de responsabilidad de las sanciones, en virtud de la cual será responsable el autor del hecho en que consista la infracción, la LTSV también establece una serie de normas generales sobre las personas responsables que, en unas ocasiones, modifican las previsiones que sobre la autoría pudieran derivarse del tipo de cada infracción y, en otras, determinan o precisan la autoría de la infracción ante la ausencia de toda mención relativa al sujeto activo en el propio tipo. Tales normas las prevé el art. 69.1 LTSV y se analizan en los apartados que siguen.

\section{Posición de garante del conductor de determinados vehículos}

Según la letra a) del art. 69.1 LTSV:

“El conductor de una motocicleta, de un ciclomotor, de un vehículo de tres o cuatro ruedas no carrozados o de cualquier otro vehículo para el que se exija el uso de casco por conductor y pasajero será responsable por la no utilización del casco de protección por el pasajero, así como por transportar pasajeros que no cuenten con la edad mínima exigida. Asimismo, el conductor del vehículo será responsable por la no utilización de los sistemas de retención infantil, con la excepción prevista en el artículo 11.4 cuando se trate de conductores profesionales". 
En este caso, se trata, como puede verse, de un supuesto de responsabilidad única del conductor de determinados vehículos por acciones u omisiones cometidas por otras personas pero respecto de las cuales la Ley atribuye al conductor una posición de garante, dando así lugar a un supuesto de comisión por omisión. El responsable es, únicamente, el conductor de tales vehículos, no el pajero que no utiliza el caso o los menores de cierta edad, pues solo es aquél, según el legislador, el sujeto que tiene el deber de impedir el resultado en que consiste la infracción: no utilizar el caso o el sistema de retención infantil, o transportar pasajeros que no cuenten con la edad mínima exigida.

Aunque el principio de personalidad de las sanciones excluye la responsabilidad por "hecho ajeno", no es contraria a dicho principio la posibilidad de que sujetos diversos al autor material de la infracción se consideren autores de la misma por no haberla impedido pudiendo -y debiendo legalmente- hacerlo. Es lo que sucede en este supuesto y en el siguiente, del que paso a ocuparme.

\section{La responsabilidad solidaria de los padres y otros sujetos por las infracciones de los menores}

También constituye un supuesto de comisión por omisión la responsabilidad solidaria de los padres, tutores, acogedores y guardadores legales o de hecho por las multas impuestas a los menores de edad, en razón al incumplimiento del deber de aquéllos de impedir la infracción cometida por éstos. Se prevé en estos términos en el art. 69.1.b):

\footnotetext{
"Cuando la autoría de los hechos cometidos corresponda a un menor de dieciocho años, responderán solidariamente con él sus padres, tutores, acogedores y guardadores legales o de hecho, por este orden, en razón al incumplimiento de la obligación impuesta a éstos que conlleva un deber de prevenir la infracción administrativa que se impute a los menores. La responsabilidad solidaria quedará referida estrictamente a la pecuniaria derivada de la multa impuesta".
}

Se trata de un supuesto que contempla en términos generales la LAP en su art. 130.3 al disponer que "serán responsables subsidiarios o solidarios por el incumplimiento de las obligaciones impuestas por la Ley que conlleven el deber de prevenir la infracción administrativa cometida por otros, las personas físicas o jurídicas sobre las que tal deber recaiga, cuando así lo determinen las leyes de los distintos regímenes sancionadores". La jurisprudencia constitucional, como es sabido, ha admitido la solidaridad en el Derecho sancionador (SSTC 76/1990, 146/1994, etc.), y lo mismo ha hecho la jurisprudencia ordinaria [SSTS de 23 de marzo de 1998 (Ar. 2828) y de 19 de diciembre de 2000 (Ar. 9572); SAN de 21 de julio de 2004 (Ar. 802). Pero se podía haber prescindido perfectamente de ella, estableciendo la coautoría de padres y meno98 dadores por su posición de garante respecto de los menores. 
En efecto, si, como es el caso, a los padres, tutores, guardadores, etc., se les hace responsables del pago de las sanciones pecuniarias por haber cometido una infracción consistente en no prevenir la infracción cometida por el menor, parece más adecuada la solución técnica que ofrece la LPSPV o el Derecho italiano que prescinden del concepto de solidaridad. El art. 9.2.b) de la LPSPV considera autores a "las personas que incumplan el deber, impuesto por una norma de rango legal, de prevenir la comisión por otro de la infracción". El precepto añade lo siguiente: "Dichas personas no responderán cuando, por cualquier motivo, no se determine la existencia de la infracción que deban prevenir o la autoría material de la persona respecto de la que el deber de prevención se ha impuesto. Si se declaran tal existencia y autoría, aquéllas responderán, aunque el autor material no sea declarado culpable por aplicación de una causa de exclusión de la imputabilidad o la culpabilidad". Por su parte, el art. 2 de la Ley italiana núm. 689, de 24 de noviembre de 1981, prevé la responsabilidad de los sujetos que tienen bajo su cuidado o vigilancia a los incapaces por las infracciones cometidas por éstos, "salvo que prueben que no han podido impedir el hecho". Si el objetivo de las sanciones es preventivo o disuasorio, esta finalidad se cumple mucho mejor con previsiones como las referidas que con la institución de la solidaridad, pues en ésta sólo responde uno cuando quizá son varios los culpables o responde incluso quien ninguna "culpa" tiene, mientras que con la extensión del concepto de autoría se sanciona a todos los culpables de la comisión de una infracción (en el ejemplo a quienes la cometen materialmente -salvo que se trate de inimputables- y a quienes no la evitaron cuando debían y podían hacerlo). Hubiera sido mejor, por ello, que la LTSV extendiera el concepto de autor a los padres, tutores, etc. por no impedir, pudiendo razonablemente hacerlo, la comisión de la infracción por el menor, fijando de paso la edad a partir de la cual se puede cometer una infracción administrativa en el sector, que no tiene por qué ser -como se verá más abajolos 18 años.

En este caso la responsabilidad de los padres, tutores, etc. también constituye, como en el anterior, un supuesto de comisión por omisión integrado por una posición de garante, supuesto que sólo tiene lugar si se vulnera el deber de prevenir la infracción de forma dolosa o imprudente. A diferencia de lo que ocurre cuando el titular del vehículo no identifica al conductor responsable, que responde por la infracción de su propio deber y no por la infracción realmente cometida por el conductor, aquí se responde por el incumplimiento del propio deber pero en relación a la infracción cometida por otro que se debía y podía evitar. Por consiguiente, el garante no debe ser sancionado si prueba que cumplió con diligencia su deber de vigilancia o prevención, esto es, si demuestra que no ha podido impedir la infracción cometida por el menor. De este modo, producida la infracción, sería el garante el que debería probar las circunstancias que le eximirían de responsabilidad. En relación a si ello supondría una inversión de la carga de la prueba se ha señalado, con carácter general, que "si el ordenamiento jurídico coloca a un sujeto en esa condición de garante, y le encomienda la realización de una actividad necesaria para impedir un concreto resultado [la comisión de la infracción por parte del menor], cuando ese resultado se produce, es inevitable deducir que la actividad impuesta por el ordenamiento jurídico no se ha realiza- 
do por quien estaba obligado a hacerlo y que no lo hizo de forma voluntaria. Si concurrieron especiales circunstancias, que hicieran imposible esa actuación, las mismas deberán ser "alegadas de forma racional y fundada por quien omitió la conducta expresamente impuesta por la norma jurídica; y ello porque tales circunstancias suponen una justificación de la omisión del comportamiento debido, cuya prueba corresponde a quien la alegue" 25 .

\section{Responsabilidad en los supuestos de no identificación del conductor}

El art. 69.1 LTSV también precisa con carácter general cuáles son los sujetos responsables en aquellos casos en los que no se procede en el acto a la identificación del conductor que ha cometido una infracción, bien porque no tiene lugar la detención del vehículo (debido a que ello puede originar un riesgo para la circulación o porque se tiene conocimiento de los hechos a través de medios de captación y reproducción de imágenes que permiten la identificación del vehículo), bien porque se trata de infracciones de estacionamiento en las que el conductor está ausente ${ }^{26}$. En tales casos la responsabilidad recaerá en el conductor habitual del vehículo (nueva figura que introduce la reciente reforma), en el titular o arrendatario del mismo o en los talleres mecánicos o establecimientos de compraventa de vehículos, todo ello de conformidad con las siguientes reglas:

“c) En los supuestos en que no tenga lugar la detención del vehículo y éste tuviese designado un conductor habitual, la responsabilidad por la infracción recaerá en éste, salvo en el supuesto de que acreditase que era otro el conductor o la sustracción del vehículo".

d) En los supuestos en que no tenga lugar la detención del vehículo y éste no tuviese designado un conductor habitual, será responsable el conductor identificado por el titular o el arrendatario a largo plazo, de acuerdo con las obligaciones impuestas en el artículo 9 bis".

e) En las empresas de arrendamiento de vehículos a corto plazo será responsable el arrendatario del vehículo. En caso de que éste manifestara no ser el conductor, o fuese persona jurídica, le corresponderán las obligaciones que para el titular establece el artículo 9 bis. La misma responsabilidad alcanzará a los titulares de los talleres mecánicos o establecimientos de compraventa de vehículos por las infracciones cometidas con los vehículos mientras se encuentren allí depositados".

25 I. López Cárcamo e I. Lasagabaster Herrante, “Artículo 9.- Autoría”, en I. Lasagabaster Herrante (dir.), Ley de la potestad sancionadora. Comentario Sistemático, Bilbao, LETE-IVAP, 2006, pp. 193-194, que citan en su apoyo la SAN de 26 de julio de 2004 (Ar. 978).

26 Sobre ello, vid. el reciente libro de M. Casino Rubio, La increible historia del deber de identificar al conductor infractor, Madrid, Civitas, 2010. 
“g) El titular o el arrendatario, en el supuesto de que constase en el Registro de Vehículos, será responsable de las infracciones por estacionamiento, salvo en los supuestos en que el vehículo tuviese designado un conductor habitual o se indique un conductor responsable del hecho".

En este sentido debe tenerse en cuenta el nuevo art. 9.bis de la LTSV, introducido por la reciente reforma de 2009. Según dicho precepto el titular de un vehículo tiene la obligación de facilitar a la Administración la identificación del conductor del vehículo con el que se ha cometido la infracción (identificación que debe incluir los datos del permiso o licencia de conducción o una copia de tales autorizaciones si el conductor no figura inscrito en el Registro de Conductores e Infractores), así como de impedir que el vehículo sea conducido por quienes nunca hubieren obtenido una autorización para conducir. El titular quedará exonerado de tales obligaciones si comunica al Registro de Vehículos de la DGT el "conductor habitual” del vehículo, recayendo en éste dichas obligaciones. Se considera conductor habitual "la persona que, contando con el permiso o licencia de conducción necesario, que estará inscrito en el Registro de Conductores e Infractores, ha sido designada por el titular de un vehículo, previo su consentimiento, en virtud de lo dispuesto en el art. 9 bis, por ser aquella que de manera usual o con mayor frecuencia conduce dicho vehícuIo" (Anexo I LTSV). Las referidas obligaciones y la comunicación del conductor habitual corresponderán al arrendatario a largo plazo del vehículo en el supuesto de que hubiese constancia de éste en el Registro de Vehículos. El titular del vehículo en régimen de arrendamiento a largo plazo debe comunicar al Registro de Vehículos el arrendamiento.

La responsabilidad del conductor habitual, del titular, del arrendatario o de los titulares de los talleres mecánicos o establecimiento de compraventa que se prevé en los apartados transcritos no lo es por la infracción realmente cometida (exceso de velocidad, incumplimiento de las normas de establecimiento, etc.), sino por la infracción consistente en no identificar verazmente al conductor responsable de la infracción cuando sean debidamente requeridos para ello en el plazo establecido [art. 65.5.j) en relación con el art. 9 bis LTSV].

\section{Responsabilidad por determinadas infracciones relativas a los vehículos}

El art. 69.1, en su letra f), también precisa que el responsable por las infracciones relativas a la documentación del vehículo, a los reconocimientos periódicos y a su estado de conservación es el titular o arrendatario al largo plazo del vehículo. Dice así el precepto:

“El titular, o el arrendatario a largo plazo, en el supuesto de que constase en el Registro de Vehículos, será en todo caso responsable de las infracciones relativas a la documentación del vehículo, a los reconocimientos periódicos y a su estado de conservación, cuando las deficiencias afecten a las condiciones de seguridad del vehículo". 
En cualquier caso, respecto a la documentación del vehículo (permiso de circulación, tarjeta ITV, etc.), debe tenerse en cuenta que quien tiene el deber de portar tales documentos y de exhibirlos cuando sea requerido para ello por los Agentes de la autoridad es el conductor del vehículo (art. 59.3 LTSV) no el titular del mismo. Éste será responsable por no poseer tales documentos del vehículo, no por no portarlos en un momento determinado. De este modo, si el conductor no los porta porque el titular no los posee, ambos serán responsables, cada uno por un tipo distinto de infracción (uno por no poseerlos y otro por no portarlos), pero si el titular posee los documentos pero en el momento de ser requerido el conductor no los porta y exhibe, solo será responsable el conductor por el incumplimiento de la obligación prevista en el art. 59.3.

También debe tenerse en cuenta que tanto en este supuesto, como en los anteriores, si el titular que figura en el Registro acredita que transmitió el vehículo con anterioridad a la comisión de la infracción, el sujeto responsable no será él (por ese simple dato formal de constar aún en el Registro) sino el titular material del vehículo. A él se le podrá sancionar por no haber comunicado el cambio de titularidad a la Jefatura Provincial correspondiente (art. 61.4 LTSV y art. 32 RGVeh), pero no por no poseer los documentos de un vehículo que ya no es suyo.

\section{Responsabilidad subsidiaria (no sancionadora) por el impago de las multas}

Por último, conviene referirse a la responsabilidad subsidiaria que para el pago de las multas prevé el art. 91 LTSV, en el capítulo relativo a la ejecución de las sanciones. Según dicho precepto:

“1. Los titulares de los vehículos con los que se haya cometido una infracción serán responsables subsidiarios en caso de impago de la multa impuesta al conductor, salvo en los siguientes supuestos:

a) Robo, hurto o cualquier otro uso en el que quede acreditado que el vehículo fue utilizado en contra de su voluntad.

b) Cuando el titular sea una empresa de alquiler sin conductor.

c) Cuando el vehículo tenga designado un arrendatario a largo plazo en el momento de cometerse la infracción. En este caso, la responsabilidad recaerá en éste.

d) Cuando el vehículo tenga designado un conductor habitual en el momento de cometerse la infracción. En este caso, la responsabilidad recaerá en éste.

2. La declaración de responsabilidad subsidiaria y sus consecuencias, incluida la posibilidad de adoptar medidas cautelares, se regirán por lo dispuesto en la Ley 58/2003, de 17 de diciembre, General Tributaria y en el Reglamento General de Recaudación. 
3. El responsable que haya satisfecho la multa tiene derecho de reembolso contra el infractor por la totalidad de lo que haya satisfecho".

Aquí ya no se trata, como en el caso de la responsabilidad solidaria de los padres, tutores, acogedores y guardadores de la responsabilidad por incumplir el deber de impedir que otro comenta una infracción administrativa, sino más simplemente de responder de forma subsidiaria del impago de una deuda que deriva de una sanción impuesta a otro. Se trataría, pues, del aseguramiento de una deuda de Derecho público que trae causa de una infracción cometida por otra persona de la cual dicha persona es responsable, en concreto el conductor del vehículo del que el responsable subsidiario es titular. Algunos penalistas califican de este modo la previsión actual del art. 31.2 CP, que hace responsable, de manera directa y solidaria, del pago de la pena de multa impuesta al autor del delito (persona física) a la persona jurídica en cuyo nombre o por cuya cuenta actuó aquél ${ }^{27}$. Pero en tales casos el TC tiene señalado (sentencias 76/1990 y 146/1994) lo siguiente: 1) Cuando se responde por sanciones ajenas éstas no pierden su carácter de sanción por el mero traslado a otros sujetos; 2) Si la responsabilidad tiene su origen en una sanción impuesta a otro parece necesario que exista algún tipo de responsabilidad subjetiva por parte de aquél. Y no está nada claro que el nuevo art. 91 LTSV cumpla este segundo requisito.

La STC 85/2006 llega incluso a considerar que las cantidades que la Administración tributaria reclama como responsables subsidiarios a los administradores de una empresa por las sanciones impuesta a ésta tienen naturaleza materialmente punitiva. Y ello porque dicha responsabilidad no deriva de los actos de otro, sino de un comportamiento que, aunque no aparece en el elenco de las infracciones tributarias, está previsto como un supuesto de responsabilidad tributaria ex art. 40 LTG y solo a ellos resulta atribuible por no haber realizado como administradores los actos necesarios que fuesen de su incumbencia para el cumplimiento de las obligaciones tributarias de la entidad, por haber consentido el incumplimiento por quienes de ellos dependía o por haber adoptado acuerdos que hicieron posible tales infracciones.

\section{LA IMPUTACIÓN PERSONAL O REPROCHABILIDAD}

\section{La imputación personal o culpabilidad en sentido estricto: contenido y fundamento}

El principio de culpabilidad también comporta la exigencia de imputación personal o culpabilidad en sentido estricto, en virtud de la cual no se puede sancionar por conductas antijurídicas a aquellos sujetos que no cumplan unas determinadas condi-

27 J. M. Silva Sánchez e I. Ortiz de Urbina, “El art. 31.2 del CP ¿responsabilidad penal de las personas jurídicas o mero aseguramiento del pago de la pena de multa), en InDret.com, Revista para el análisis del Derecho, núm. 343, 2006, p. 39. 
ciones que le permitan una acceso normal al mensaje de las normas ${ }^{28}$. Resulta pues necesario que el incumplimiento de la norma, para el que se ha previsto la sanción, sea imputable al sujeto que la incumple, que a dicho sujeto se le pueda hacer responsable de dicho incumplimiento, lo que no ocurre en los supuestos de minoría de edad (que a estos efectos no tiene por qué coincidir con la general), de enfermedad mental, error de prohibición, etc., que por eso se denominan supuestos de inimputabilidad.

Nuestro Derecho administrativo no ha prestado la debida atención a la culpabilidad así entendida. La LAP no dice nada al respecto, como tampoco la legislación sectorial. Sólo algunas leyes como la General Tributaria contempla algún supuesto concreto de inimputabilidad. Así, el art. 179.2 de la misma señala que las acciones u omisiones tipificadas en las leyes no darán lugar a responsabilidad por infracción tributaria en los siguientes supuestos: "a) cuando se realicen por quienes carezcan de capacidad de obrar en el orden tributario”. El art. 6 LPSPV, bajo el rótulo Causas de exención de la responsabilidad, se remite a las causas específicas que prevea la legislación sectorial y a los supuestos contemplados en el CP, "siempre que sean compatibles con la naturaleza y finalidad de la infracción concreta y de la regulación sectorial de que se trate, y, en su caso, con las matizaciones que se determinen en ellas", y regula con carácter general tanto el error de prohibición (vencible e invencible), como la minoría de edad.

En la jurisprudencia se puede destacar la STS de 23 de febrero de 2005, Sala de lo Militar (Ar. 4171), a tenor de la cual:

"A través de la regulación de la circunstancia eximente de la alteración mental prevista en el art. 20.1 CP, se ha incorporado indirectamente una base positiva para definir lo que es la imputabilidad en nuestro Derecho, puesto que lo determinante para aceptar la alteración mental no es ya la base patológica, sino la trascendencia de la alteración hacia la capacidad del sujeto para comprender la ilicitud del hecho o para actuar conforme a esta comprensión [... ]. La fórmula de la imputabilidad o capacidad de culpabilidad, se compone de dos elementos: uno biológico y otro normativo, de tal manera que no sólo se requiere una determinada enfermedad mental sino que ésta impida al autor comprender la antijuridicidad y comportarse de acuerdo con esta comprensión".

Por eso, desde la teoría de la infracción administrativa, cabe sostener que la comisión de un hecho típicamente antijurídico no determina de forma automática la imposición de la sanción correspondiente. Existen determinados supuestos en los que el autor del hecho antijurídico queda exento de responsabilidad y no puede ser sancionado. Aquí entra en juego la culpabilidad como segundo elemento de la infracción, aunque no hay acuerdo acerca de si en la culpabilidad entendida como elemento del delito o la infracción debe estudiarse también la exigencia de dolo o culpa. En mi opinión, como ya he adelantado, el dolo y la culpa encuentran un mejor acomodo sistemático en la antijuridicidad como primer elemento de la teoría de la infracción administrativa, y dentro de ella en la tipicidad (que lo que hace muchas veces es positivizar precisa-

28 S. Mir Puig, Derecho penal..., cit., p. 141. 
mente las normas de cuidado), aunque nuevamente lo importante es que el dolo y la culpa han de estar presentes y alguna vez han de aparecer en la teoría de la infracción $^{29}$. En efecto, si la antijuridicidad es la relación de contradicción de una conducta con el Derecho, en el ámbito sancionador sólo puede darse tal relación si la conducta es dolosa o imprudente, pues una conducta en la que no concurran tales notas no vulnera norma alguna, no puede ser prohibida por el Derecho y, por tanto, no se puede calificar de antijurídica a efectos sancionadores. El dolo o la imprudencia son elementos esenciales (implícitos, si se quiere) en la descripción de la conducta prohibida u ordenada por la norma sancionadora (parte subjetiva del tipo). Por eso se habla de tipos dolosos y tipos imprudentes de infracción. La culpabilidad como elemento de la infracción ha de ocuparse únicamente de las condiciones que permiten imputar un comportamiento antijurídico concreto a su autor. A diferencia de la antijuridicidad que es un juicio de desvalor general o despersonalizado, la culpabilidad así entendida es un juicio personalizado o concreto. Así lo entiende la Ley alemana de contravenciones que define el ilícito administrativo como "todo hecho antijurídico (antijuridicidad) y reprochable (culpabilidad) que integra el supuesto de hecho de una Ley para el que esté previsto la imposición de una multa administrativa".

La culpabilidad o imputación personal constituye, pues, la parte o elemento de la teoría de la infracción que determina los elementos o condiciones bajo las cuales el autor es responsable ("culpable") por el hecho antijurídico cometido. En este sentido hay que señalar que actúa de forma culpable la persona a la que se le puede exigir que actúe de conformidad con las normas. En la culpabilidad se individualiza o subjetiviza la responsabilidad del infractor, se consideran los factores individuales de la infracción ${ }^{30}$. En realidad, lo que en el concepto dogmático de culpabilidad se estudia no son tanto los elementos que determinan la responsabilidad o exigibilidad del autor, cuanto su reverso, esto es, las condiciones que impiden esa exigibilidad o culpabilidad y que por eso se les suele denominar causas de exclusión de la culpabilidad. Estos supuestos son, en el ámbito penal, la minoría de edad, las anomalías o alteraciones psíquicas, el error de prohibición y el miedo insuperable ${ }^{31}$. La mayoría de los autores entienden que también son de aplicación al ámbito administrativo ${ }^{32}$. Y países como Italia y Alemania han previsto igualmente algunos de tales supuestos en sus respectivas Leyes ${ }^{33}$.

29 Como señala E. Gimbernat Ordeig, Estudios..., cit., para el delito, "lo que importa al que quiere estudiar Derecho penal es que el dolo (con sus distintas clases) se lo expliquen alguna vez; y esto -antes o después- los dos sistemas [el causalista y el finalista] lo hacen" (p. 164).

30 M. Gómez Tomillo, Derecho Administrativo Sancionador. Parte General, Cizur Menor, Aranzadi, 2008, p. 379.

31 Otros autores añaden el estado de necesidad exculpante (conflicto entre bienes iguales), y el encubrimiento entre parientes, de los que no nos vamos a ocupar aquí.

32 L. Martín-Retortillo, “Multas administrativas”, en RAP núm. 79, 1976, cp. 45; M. Rebollo Puig, Potestad..., cit., pp. 645 y ss.; M. Rebollo y M. Izquierdo, Manual de la Inspección de consumo, Madrid, INC, 1998, p. 73; A. de Palma del Teso, El principio de culpabilidad..., cit., pp. 179 y ss.; G. Quintero Olivares, "La autotutela...", cit., pp. 267-269

33 La Ley alemana de contravenciones prevé expresamente la minoría de edad y la alteración psíquica, cuando en su art. 12 dispone que: "1. No actúa de forma recriminable quien en el momento 
Tales supuestos tienen cabida en el Derecho Administrativo Sancionador, en general, y en las infracciones de tráfico, en particular. La razón de ello no reside tampoco en una traslación sin más de los principios penales al ámbito administrativo, sino en el propio fundamento material de tales causas de exclusión de la culpabilidad, también presente en el ordenamiento administrativo sancionador.

Su fundamento hay que conectarlo igualmente con la función de las normas sancionadoras. Si éstas tratan fundamentalmente de dirigir u orientar la conducta de los ciudadanos al objeto de conseguir que el comportamiento del destinatario de la norma se adecue al mandato o prohibición que la misma contiene, de modo que el bien jurídico que esta trata de proteger no sufra menoscabo, parece claro que para que la norma cumpla esta función es preciso que el sujeto al que se dirige pueda ser motivado por la misma, esto es, se encuentre en condiciones normales de accesibilidad a la motivación de la norma. Pues bien, esta accesibilidad falta en los supuestos citados de minoría de cierta edad, trastorno psíquico, desconocimiento invencible de la antijuridicidad (error de prohibición), no exigibilidad de otra conducta y miedo insuperable ${ }^{34}$. Se trata de supuestos de inimputabilidad, es decir, supuestos en los cuales un sujeto no es imputable por no ser susceptible de motivación mediante las normas. De este modo sólo actúa culpablemente el sujeto al que puede exigírsele actuar de conformidad a las normas sancionadoras. Los supuestos de inimputabilidad que con mayor frecuencia pueden darse en el sector del tráfico son los siguientes.

de cometer el hecho no ha cumplido los catorce años. Un adolescente sólo actúa de forma recriminable en el marco de la Ley del Tribunal de menores. 2. No actúa de forma recriminable quien en el momento de cometer el hecho, por perturbaciones psicológicas de origen patológico, profundos trastornos de consciencia, deficiencias mentales y otra grave anomalía psíquica, es incapaz de percibir la ilicitud de la conducta o de actuar sobre la base de dicha percepción". Y el art. 2.1 de la Ley italiana dispone que: "No puede imponerse una sanción a quien en el momento de cometer el hecho no haya cumplido los dieciocho años o no tenga, en base a los criterios indicados en el Código penal, capacidad de obrar, a menos que el estado de incapacidad sea debido a su culpa o producto de su propia conducta".

34 En sentido similar, A. de Palma del Teso, El principio..., cit., p. 179. Como ha señalado E. Gimbernat Ordeig, Estudios..., cit., con el juicio de antijuridicidad el legislador coloca un factor general condicionante para que los ciudadanos se abstengan de realizar determinadas conductas. Existen, no obstante, ciertas personas en referencia a las cuales sociológicamente se admite, sin más, que son inaccesibles a la motivación de la pena; bien por su ininmputabilidad permanente o transitoria, bien porque -al desconocer la prohibición- no han tenido tampoco ocasión de dejarse influir por ella. Por estar suficientemente delimitado quiénes son esas personas, en estos casos se puede prescindir de imponer la pena sin que sufra por ello detrimento la prevención general; pues los imputables saben que para ellos esa impunidad no rige y, por ello, siguen teniendo los mismos motivos (el de eludir la imposición de la pena) para comportarse de acuerdo a Derecho; y los "inculpables", por su parte, al no ser accesibles -por diferentes causas- a la motivación punitiva, no van a delinquir más o menos porque se les castigue o se les deje de castigar". También fundamentan la culpabilidad en la función motivadora de las normas penales, entre otros, S. Mir Puig, Derecho penal..., cit., que alude a la "anormalidad motivacional como fundamento de la exclusión de la responsabilidad penal” (pp. 541 y ss.); F. Muñoz Conde y M. García Arán, Derecho..., cit., p. 396; J. M. Silva Sánchez, Aproximación..., cit., quien junto a las razones de prevención añade consideraciones garantísticas, como son la igualdad, la humanidad, la condescendencia ante debilidades humanas, etc. (p. 662). 


\section{La minoría de edad}

La doctrina hace ya tiempo que demandó "criterios claros y elementales" que resuelvan el importante problema de quienes son los sujetos sobre los que pueden recaer las sanciones administrativas, en particular en lo relativo a la minoría de edad $^{35}$. Pero nuestro Derecho sigue guardando silencio sobre la edad a partir de la cual una persona puede ser sancionada, salvo la LPSPV que con buen criterio dispone en su artículo 6.3 que "las normas sancionadoras sectoriales, en atención a la naturaleza y finalidad de la concreta regulación material sectorial de que se trate y a la capacidad de obrar que en dicha regulación se reconozca a los menores, fijarán el límite de edad a partir del cual se puede ser responsable de una infracción. A falta de disposición al efecto, no serán responsables los menores de 14 años". En otros Derechos, como el alemán y el italiano, se establece con carácter general que la edad a la que se responde por la comisión de las infracciones administrativas son los catorce y dieciocho años, respectivamente. Esta última es la edad que rige en materia penal tras el nuevo Código de 1995, si bien el menor de dieciocho años que cometa un hecho delictivo podrá ser responsable con arreglo a lo dispuesto en la Ley de responsabilidad penal del menor (art. 19), ley que se aplica a partir de los 14 años (art. 1 de la Ley orgánica 5/2000, de 12 de enero, reguladora de la responsabilidad penal de los menores).

Algunos autores han propuesto acudir a la edad penal, mientras que otros consideran que la edad para poder ser sancionado debe vincularse a la capacidad para ser titular de derechos y obligaciones en el ámbito administrativo ${ }^{36}$. Sin embargo, como reconocen quienes mantienen este último criterio, quedan sin resolver los supuestos en que el menor no tiene reconocida la capacidad administrativa en el sector del ordenamiento de que se trate y, sobre todo, el problema de los menores que

35 L. Martín-Retortillo, “Multas...”, cit., pp. 45-46.

36 M. Montoro Puerto, La infracción administrativa, Barcelona, Nauta, 1965, p. 146. En opinión de L. Martín-Retortillo, “Multas...”, cit., desde el momento en que "a los menores se les reconozca de forma expresa la posibilidad de ejercicio de determinados derechos o facultades, parece lógico pensar que, del mismo modo, han de estar sometidos a las potestades sancionatorias que la Administración tiene atribuidas para cuidar del correcto ejercicio de tales derechos o facultades. Como modelo podrían recordarse las facultades otorgadas a los menores por el Código de la Circulación o la Ley de Caza" (p. 46). Pero como señala el mismo autor, con este criterio queda sin resolver el problema de aquellos casos en que no se estén actuando unas facultades expresamente concedidas, como el peatón que no respeta un semáforo, ¿será sancionable siempre, aunque sea un niño? (p. 46). M. Rebollo Puig, Potestad..., cit., también entiende que el criterio de la capacidad para ser titular de derechos y obligaciones en el ámbito administrativo puede conducir a resultados insatisfactorios porque también los niños tienen expresamente reconocida la facultad de usar los servicios públicos o los bienes demaniales y, no obstante, parece excesivo considerar que son imputables a efectos de las infracciones que cometan. Por ello propone desvincular la imputabilidad del reconocimiento de capacidad para ejercer ciertos derechos y facultades y propone la edad de dieciséis años, por entender que el ordenamiento jurídico parte de que la capacidad para tener dolo o culpa no se tiene antes de esa edad, citando en su apoyo no sólo el CP sino también la hoy derogada Ley de Orden Público (art. 24.1). A pesar de estos inconvenientes, A. De Palma del Teso, El principio..., cit., sigue defendiendo la "idea de reconducir la capacidad para cometer ilícitos administrativos a la idea de capacidad administrativa. A partir del momento en que el Ordenamiento reconozca capacidad para ser sujeto de derechos y obligaciones y operar personalmente en el sector concreto ejercitando los propios derechos, podrá ser tenido como sujeto activo de una infracción administrativa” (p. 184). 
tienen reconocida la facultad de usar los servicios públicos o, en nuestro caso, las vías públicas ${ }^{37}$.

En efecto, en el sector que nos ocupa el criterio de la capacidad administrativa puede conducir a resultados como los siguientes: un peatón menor de once años podría ser sancionado por no respetar un semáforo ya que tiene capacidad para usar las vías públicas; pero un menor con diecisiete no sería sancionado por utilizar un automóvil de los que requieren permiso de conducir de la clase $B$, ya que la edad para obtener dicho permiso y, por tanto, la edad para tener la capacidad necesaria para su utilización, son los dieciocho años [art. 4.2.e) del Reglamento General de Conductores]; pero el mayor de quince años que con un ciclomotor, que no porta pasajeros, no respeta un paso para peatones sí podría ser sancionado por tener capacidad para conducir el mismo a partir de esa edad [art. 4.2.a) del Reglamento General de Conductores]. El criterio, como se ve, es insatisfactorio y el responsable no es otro que el legislador general y el sectorial de tráfico. Aunque la LTSV parece reconocer la responsabilidad de los menores de 18 años cuando consagra la responsabilidad solidaria de sus padres, tutores, etc. en el pago de las sanciones pecuniarias [art. 69.1.b)], es claro que hay que fijar un límite por abajo, ya que no parece lógico -ni coherente con el fundamento mismo de la culpabilidad-sostener la responsabilidad de un menor de 11 o 12 años.

A falta de un criterio claro, que evite la inseguridad reinante, en mi opinión la edad mínima para poder ser sancionado en materia de tráfico son los 15 años. Aunque esta afirmación puede parecer tan convencional y criticable como cualquier otra, en su favor juegan algunos datos de Derecho positivo y el propio fundamento de la culpabilidad.

Los quince años, en efecto, es la edad mínima requerida para obtener una licencia de conducción (de la clase AM), que autoriza a conducir ciclomotores de dos o tres ruedas y cuatriciclos ligeros [art. 6.2.a) del Reglamento general de conductores]. Para la obtención de dicha licencia es preciso, entre otros requisitos, la realización y superación de una prueba de control de conocimientos específica en la que los solicitantes demuestren "que poseen un conocimiento razonado y una buena compresión" de las "normas y señales reguladoras de la circulación, cuestiones, factores, equipos y elementos de seguridad concernientes al conductor, al vehículo y, en su caso, a la carga transportada (art. 47.1 y Anexo V.B.2 último párrafo del Reglamento General de Conductores). Los propios poderes públicos, en este caso la Administración, están reconociendo expresamente que a partir de los catorce años se tiene la capacidad suficiente para entender y comportarse de conformidad con las normas que regulan el tráfico, por lo que a partir de esa edad no cabe hablar de inimputabilidad en este sector. Ello no deriva de la vinculación entre imputabilidad y reconoci-

37 Como ha señalado M. Rebollo Puig, Potestad..., cit., este criterio resulta especialmente insuficiente cuando se trata de deberes de no hacer referidos a los menores -no conducir determinados vehículos- atendiendo además a su supuesta incapacidad para realizar correctamente la actividad que se les prohíbe (p. 646). 
miento de la capacidad para ejercer ciertos derechos y facultades, sino del propio fundamento de la culpabilidad, a saber: la accesibilidad a la motivación de las normas, la posibilidad de poder ser motivados por las normas y entender el reproche por su contravención. La legislación de tráfico entiende que a partir de los quince años los ciudadanos pueden actuar de conformidad con las normas, de modo que tales sujetos actúan culpablemente y pueden ser sancionados si no actúan de conformidad con las mismas ${ }^{38}$. A partir de esa edad, en definitiva, les puede hacer un reproche castigar por incumplir las normas pues ya están en condiciones físicas y psíquicas de cumplirlas. Pero el legislador debería preverlo de forma expresa.

Otra cuestión es el tipo de sanciones que cabe a imponer a los menores por la comisión de estas u otras infracciones. Como con toda razón se ha señalado, sería deseable prever un tipo de sanciones específicas para los menores de edad, pues parece evidente que la sanción pecuniaria no resulta la más adecuada para las infracciones cometidas por los menores, pudiendo resultar más eficaz y, sobre todo, la más acorde con los propios intereses de los menores las sanciones de finalidad o contenido educativo 39 .

\section{El trastorno psíquico y la inimputabilidad por consumo de alcohol}

La ausencia en el ordenamiento administrativo de una regulación de la inimputabilidad, ha llevado a los autores a sostener distintas posturas en relación a tales causas: para unos debe acudirse a las eximentes del art. 20.1 y 2 del CP, para otros las alteraciones psíquicas no excluyen la responsabilidad en el Derecho administrativo sancionador, otros, en fin, consideran que debe vincularse la imputabilidad con la capacidad para ser titular de derechos y obligaciones en el ámbito administrativo. El TS parece inclinarse por la primera postura ya que entiende que "el concepto de imputabilidad penal puede ser estimado con igual valor en la jurisdicción contenciosoadministrativa" ${ }^{40}$. En este sentido conviene recordar que según el referido precepto está exento de responsabilidad:

38 Cuestión distinta es el tipo de infracción que los mayores de quince años pueden cometer. Así, por ejemplo, el mayor de quince años que conduce un vehículo para el que se exige estar en posesión de un permiso de la clase B y no cede el paso en una glorieta o realiza indebidamente un adelantamiento, ¿Puede ser sancionado por todas las infracciones cometidas?. Sobre el tema, vid. mi libro Las sanciones de tráfico, de próxima publicación.

39 A. de Palma del Teso, El principio..., cit., p. 186. Como la propia autora señala, la Convención sobre los Derechos del Niño, adoptada por la Asamblea General de las Naciones Unidas el 20 de noviembre de 1989, establece expresamente que "en todas las medidas concernientes a los niños que tomen las instituciones públicas o privadas de bienestar social, los tribunales, las autoridades administrativas o los órganos legislativos, una consideración primordial a que se atenderá será el interés superior del niño". Sobre dicha Convención, L. Martín-Retortillo, La Europa de los derechos humanos, Madrid, CEC, 1998, pp. 319 y ss.

40 STS de 6 de octubre de 1978 (Ar. 3036). En la sentencia de 14 de febrero de 1984 (Ar. 629), aplica esta circunstancia como atenuante en una sanción de separación definitiva del servicio impuesta a un funcionario por una falta grave de abandono de servicio, afirmando que "el grado de imputabilidad del sancionado, se ve aquí sensiblemente disminuido en función de la depresión psíquica que le aquejaba, y que fue determinante de la inasistencia al desempeño de su función". Tomo la referencia de ambas sentencias de A. de Palma del Teso, El principio..., cit., p. 188, nota núm. 21. 
“1. El que al tiempo de cometer la infracción penal, a causa de cualquier anomalía o alteración psíquica, no pueda comprender la ilicitud del hecho o actuar conforme a esa comprensión. El trastorno mental transitorio no eximirá de pena cuando hubiese sido provocado por el sujeto con el propósito de cometer el delito o hubiera previsto o debido prever su comisión

2. El que al tiempo de cometer la infracción penal se halle en estado de intoxicación plena por el consumo de bebidas alcohólicas, drogas tóxicas, estupefacientes, sustancias psicotrópicas u otras que produzcan efectos análogos, siempre que no haya sido buscado con el propósito de cometerla o no se hubiese previsto o debido prever su comisión, o se halle bajo la influencia de un síndrome de abstinencia, a causa de su dependencia de tales sustancias, que le impida comprender la ilicitud del hecho o actuar conforme a esa comprensión.

3. El que, por sufrir alteraciones en la percepción desde el nacimiento o desde la infancia, tenga alterada gravemente la conciencia de la realidad".

En el concreto sector del tráfico se ha sostenido que la enajenación mental, en los casos en que el bien protegido es la seguridad vial y la norma conculcada es una de las de comportamiento en la circulación con vehículos de motor, resulta de muy difícil estimación, precisamente porque la enajenación mental es causa impeditiva para obtener la correspondiente autorización administrativa ${ }^{41}$. En mi opinión, sin embargo, esta argumentación sirve precisamente para sostener lo contrario: la estimación de la enajenación mental como causa de inimputabilidad o de exclusión de la culpabilidad. Si la propia normativa de tráfico declara de forma expresa y general que quienes padecen trastornos mentales no pueden obtener la correspondiente autorización para conducir vehículos de motor es, precisamente, porque carecen de la capacidad suficiente para ser motivados por las normas de tráfico. La aplicación de las normas sancionadoras a tales personas carece de toda justificación y resulta arbitraria desde el momento en que tales normas pierden su función característica. Como es obvio, lo anterior no quiere decir que todas las enfermedades o deficiencias psicofísicas que impiden obtener el permiso o licencia de conducción (como las relativas a la capacidad visual o auditiva, al sistema locomotor, al sistema cardiovascular, trastornos hematológicos, etc.) constituyan causas de imputabilidad $^{42}$. Como señala la STS de 23 de febrero de 2005, Sala de lo Militar (recurso núm. 14/2003): no basta con determinada enfermedad mental, sino que se requiere que la misma "impida al autor comprender la antijuridicidad y comportarse con esta comprensión". De ahí la necesidad de un pronunciamiento normativo expreso sobre el particular que la actual legislación de tráfico, como en otros muchos aspectos, no realiza.

En cuanto a la inimputabilidad por consumo de alcohol, la referencia del CP a que la circunstancia solo se puede alegar como eximente "siempre que no se haya busca-

$110 \quad \begin{array}{ll}\text { M. María Muñoz Medina, La potestad..., cit., p. 162-163. } \\ 42 & \text { Vid. el anexo IV del nuevo RGCond. }\end{array}$ 
do con el propósito de cometerla [la infracción] o no se hubiese previsto o debido prever su comisión", conduce a que la misma no pueda ser apreciada en el sector que nos ocupa donde, como se sabe, se tipifica expresamente como infracción la conducción con determinadas tasas de alcohol en la sangre. En este caso el autor es inimputable en el momento de la realización del resultado típico (la conducción en estado de embriaguez, que, en rigor, y para que pudiera sostenerse dicha inimputabilidad, daría lugar a la comisión del delito del art. 379.2 CP y no a la infracción administrativa de conducir por encima de determinadas tasas de alcohol), pero en un momento anterior en el que todavía era imputable crea, de forma dolosa o imprudente, una causa del resultado (el consumo de alcohol). Es lo que se denomina actio libera in causa, acción libre en la causa. Como el autor se coloca libremente en una situación de inimputabilidad, el momento temporal para apreciar la concurrencia o no de imputabilidad no es el de la comisión de la infracción, sino uno anterior, de manera que la imputabilidad va referida a las condiciones físicas y psíquicas del sujeto anteriores a la realización de la conducta antijurídica. Es decir, la imputación no se conecta con la conducción durante la embriaguez sino con el hecho de embriagarse previamente. Se evita así, por lo demás, la contradicción que supondría el que la misma conducta (la conducción con ingesta de alcohol) se configure a la vez como infracción y como causa de exclusión del ilícito.

\section{El error de prohibición: relevancia de la actividad desesmpeñada, tolerancia y error inducido por la propia Administración}

La presencia de una infracción administrativa, al igual que la presencia de un delito, requiere que el sujeto que realiza la acción antijurídica sepa, o pueda saber, que la misma se halla prohibida por el Derecho. Cuando tal conocimiento falta, se habla de error de prohibición, en contraposición al error de tipo que supone el desconocimiento de la situación descrita por el tipo.

El error de tipo (tradicionalmente error de hecho) supone el desconocimiento de una circunstancia o elemento que pertenece a la situación descrita por el tipo legal, mientras que en el error de prohibición (error de Derecho) se conoce esa circunstancia pero se ignora que su realización es antijurídica, que está prohibida por el Derecho. Así, incurre en error de tipo, el conductor que lleva un permiso de conducir caducado ignorando tal hecho (ya que desconoce un elemento o circunstancia esencial del tipo de infracción del art. 59.3 LTSV, que requiere portar "el permiso de conducir válido"), mientras que comete error de prohibición quien circula con un permiso de conducir que sabe ha caducado pero ignorando que ello está prohibido por la normativa reguladora del tráfico; el peatón que sabe que está circulando por una autopista pero ignora que dicho comportamiento está prohibido (art. 49 LTSV); la empresa de automóviles que sabe que la publicidad de sus vehículos "incita a la velocidad excesiva” pero desconoce que ello no está permitido (art. 52 LTSV), o el funcionario de la DGT que desconoce que el Reglamento de Escuelas Particulares de Conductores prohíbe la prestación de sus servicios en una Autoescuela. Para poder 
sancionar no basta, por tanto, con que quien realiza el hecho conozca la situación típica (ausencia de error de tipo), sino también que sepa o pueda saber que su actuación se halla prohibida por el Derecho (no concurrencia de un error de prohibición).

El error de prohibición, sea vencible o invencible, no afecta al dolo del sujeto. Lo deja intacto, porque el objeto del dolo no es la antijuridicidad de la acción sino, según la tesis más autorizada, las circunstancias del hecho ${ }^{43}$. El objeto de desconocimiento o ignorancia en el error de prohibición es lo ilícito o injusto (la antijuridicidad del comportamiento), por lo que no es necesario el conocimiento de la sanción correspondiente: por ejemplo, no cabe alegar error de prohibición cuando se sabe que está prohibido circular sin espejo retrovisor pero se ignora si la infracción es leve o grave y la sanción es la prevista para una u otra. Dentro de la teoría de la infracción, el error de tipo se ubica sistemáticamente en la antijuridicidad, mientras que el error de prohibición excluye la culpabilidad ${ }^{44}$. La jurisprudencia contencioso-administrativo, sin embargo, no hace especiales esfuerzos a la hora de distinguir uno y otro tipo de error y menos se ocupa aún de su ubicación sistemática en la teoría de la infracción ${ }^{45}$. Pero mientras no haya una referencia expresa en el Derecho Administrativo Sancionador, como la hay ,por ejemplo, en la LPSPV, resulta de aplicación analógica el art. 14 del CP que distingue ambos tipos de error y ofrece un diverso tratamiento de ellos.

El error de prohibición en el Derecho administrativo sancionador ha sido admitido tanto por la doctrina como por la jurisprudencia, aplicándole las consecuencias del antiguo art. 6 bis a) del CP ${ }^{46}$. El TC ha admitido el error de prohibición en el ámbito administrativo en su sentencia 76/1990, de 26 de abril, en la que declara lo siguiente:

"la falta de mención expresa del error de Derecho como causa de exención de responsabilidad por infracción tributaria ... no es prueba, como pretenden los demandantes, de la configuración de un régimen de responsabilidad objetiva ni de la inexistencia de esa causa de exención. Si no hay responsabilidad objetiva, no es necesario que se haga constar expresamente el error de Derecho como causa que exonere de dicha responsabilidad, mas ello no significa que resulte irrelevante ni que la Ley 10/1985 lo haya excluido de los supuestos que eximen de responsabilidad

43 C. Roxin, Derecho penal..., cit., pp. 460 y 862.

44 La STS, Sala $2^{\mathrm{a}}$, de 5 de febrero de 2001 (Ar. 1231) lo afirma atinadamente: "el error de tipo, como problema de tipicidad que afecta a algún elemento esencial de la infracción, o el error de prohibición, como problema de culpabilidad por la creencia errónea de obrar lícitamente...".

45 M. Izquierdo Carrasco, "La culpabilidad y los sujetos responsables", en M. Rebollo Puig, M. Izquierdo Carrasco, L. Alarcón Sotomayor y A. Bueno Armijo, Derecho Administrativo Sancionador, Valladolid, Lex Nova, 2010, p. 326, quien sostiene incluso que, como en el Derecho administrativo sancionador no existe una regulación similar a la del $\mathrm{CP}$, las consecuencias en la apreciación de uno y otro tipo de error son las mismas.

46 En la doctrina, entre otros, M. Rebollo Puig, Potestad..., cit., p. 654; A. Nieto García, Derecho..., cit., pp. 363 y ss.; A. de Palma del Teso, El principio..., cit., p. 161; M. Gómez Tomillo, Derecho Administrativo Sancionador..., cit., pp. 404 y ss. 
por infracción tributaria. Precisamente porque la ley vincula esta responsabilidad a una previa conducta culpable, es evidente que el error de Derecho -singularmente el error invencible- podrá producir los efectos de exención o atenuación que le son propios en un sistema de responsabilidad subjetiva, pero su falta de contemplación expresa en la norma no constituye defecto de inconstitucionalidad".

EI TS, sala 5a, de 18 de octubre de 2002 (Ar. 9381) lo define así: "el error de prohibición se refiere a la representación equivocada de las consecuencias antijurídicas de la propia conducta, por creer en la ausencia de ilicitud". Y en la sentencia, sala $3^{\mathrm{a}}$, de 2 de noviembre de 1987 (Ar. 7764) se afirma que:

"desde una faceta subjetiva, no cabe negar que una diferencia de criterio razonable
y razonada respecto de la interpretación de las normas tributarias, a menudo ambi-
guas y frecuentemente complejas, puede ser causa de exclusión de la culpabilidad.
El principio en virtud del cual la ignorancia de las leyes no excusa de su cumplimien-
to (art. 6.1 CC) ha de ser matizado en el ámbito de la potestad sancionadora, me-
diante las circunstancias subjetiva y objetivas concurrentes y, por ello, determinan-
tes de la actuación o inactividad del inculpado" 47 .

Hoy el art. 14.3 del CP, aplicable aquí por analogía (in bonus) dispone que "el error invencible sobre la ilicitud del hecho constitutivo de la infracción penal excluye la responsabilidad criminal. Si el error fuera vencible, se aplicará la pena inferior en uno o dos grados". La LPSPV también lo recoge, junto al error de tipo, en su artículo 6 en estos términos: "El error sobre un elemento del tipo o sobre la ilicitud del hecho constitutivo de la infracción solamente eximirá de responsabilidad si fuera invencible. El error vencible únicamente tendrá efecto atenuante si supone disminución del grado de imprudencia. Si el dolo es elemento integrante del tipo infractor aplicado, el error vencible también eximirá de responsabilidad. El error sobre una circunstancia agravante impedirá su apreciación si es invencible. Si fuese vencible podrá tener efecto atenuante respecto del tramo de sanción que se relacione con la apreciación de la circunstancia agravante".

El error de prohibición (o la ausencia de conocimiento del ilícito) puede derivar de una idea equivocada acerca de lo ilícito o de una falta de tal idea: el sujeto puede suponer erróneamente que su comportamiento no es antijurídico (idea equivocada positiva) o puede no pensar en absoluto en el injusto (ausencia de idea) ${ }^{48}$. Un ciclista puede suponer erróneamente que, a diferencia de lo que ocurre en el caso de los conductores de vehículos de motor, no está prohibido circular en bicicleta con determinadas tasas de alcohol (vid. art. 12.1 LTSV), o ni siquiera plantearse, cuando se ha tomado varias cervezas y coge su bicicleta para reemprender la marcha, que su comportamiento puede ser antijurídico. Lo relevante, en cualquier caso, no es una u otra

47 En sentido similar las SSTS de 9 de diciembre de 1997 (Ar. 485 de 1998), 19 de diciembre de 1997 (Ar. 524 de 1998) y 15 de enero de 1998 (Ar. 789), STS de 18 de octubre de 2002, Sala de lo Militar, (Ar. 9381), todas ellas relativas al error en la interpretación de las normas.

48 G. Jakobs, Derecho penal..., cit. p. 673. 
forma de error, ya que ambas modalidades del error de prohibición deben tratarse del mismo modo, sino si el error mismo es o no evitable, es decir, si el error es vencible o invencible. Con ello se hace referencia a la responsabilidad por el error, lo que sí tiene consecuencias jurídicas.

El error de prohibición es invencible (o inevitable) cuando el autor no es responsable de él, cuando el desconocimiento de la antijuridicidad del hecho no ha podido evitarse observando la diligencia o el cuidado debido. Excluye toda responsabilidad, pues quien no ha tenido posibilidad alguna de acceder al conocimiento de la norma no ha podido ser motivado por ella, no ha podido adecuar su comportamiento a la misma y, por tanto, actúa sin culpabilidad y no puede ser castigado. En tal caso se actúa de modo típico y antijurídico, pero no culpable

El error vencible es el que hubiera podido evitarse con mayor cuidado, es decir, aplicando la diligencia debida. Por eso puede decirse que el error es evitable cuando el autor es responsable de él ${ }^{49}$. El error vencible no excluye la responsabilidad, pues si el sujeto hubiera obrado diligentemente habría podido conocer el contenido de la norma, pero atenúa la pena o la sanción. Se ha sostenido, sin embargo, que la consecuencia jurídica del error vencible de prohibición es la exclusión del dolo y la conversión de la conducta en imprudente, con la importante consecuencia de que en los tipos de infracciones que sólo admiten la forma dolosa no sería posible sancionar dicho error por imprudencia y determinaría la atipicidad de la conducta ${ }^{50}$. Sin embargo, sostener que el error de prohibición vencible excluye el dolo y permite calificar la conducta de imprudente no se adecua a la concepción mayoritaria del dolo (que ve en él el desconocimiento del hecho realizado y no de la antijuridicidad del mismo), no goza de base legal alguna (el CP, que resultaría de aplicación analógica, dice que se atenúa la pena, no que la conducta pase a ser imprudente como señala expresamente para el error de tipo) y da lugar además a resultados injustos y desproporcionados: la irresponsabilidad en los tipos de infracciones que sólo admiten la forma dolosa tanto de quienes ignoraban de forma inevitable la prohibición (error invencible), como la de

49 G. Jakobs, Derecho penal..., cit., p. 675. No se trata, como señala este mismo autor, de la evitabilidad del error como fin es sí mismo, sino que se alude a la evitabilidad del comportamiento injusto a través de la evitabilidad del error de prohibición: mediante la evitación de considerar que está permitido que el vehículo adelantado aumente la velocidad o efectúe maniobras que impidan o dificulten el adelantamiento lo que se pretende realmente es evitar tales comportamientos antijurídicos (art. 35.1 LTSV), dado el peligro que entrañan.

50 A. de Palma del Teso, El principio..., cit., p. 159. La solución depende, como señala en nota la propia autora, de la concepción del dolo que se adopte. Si se considera que el dolo no sólo incluye el conocimiento y voluntad de la situación descrita por el tipo sino también la conciencia de que el hecho realizado es contrario a Derecho (dolus malus), el error de prohibición excluye el dolo y, en función de que sea vencible o invencible y el delito o infracción de que se trate admita o no la forma imprudente, podrá ser sancionado el hecho como imprudente (es la denominada teoría del dolo). Si se considera, sin embargo, que la consciencia de la antijuridicidad no forma parte de dolo y que éste sólo incluye el conocimiento y voluntad del hecho realizado (dolo natura), el error de prohibición no excluye el dolo, sino que elimina (error invencible) o atenúa (error vencible) la culpabilidad (es la denominada teoría de la culpabilidad, mayorita$114 \quad 863$ y ss.; S. Mir Puig, Derecho penal..., cit., pp. 257 y ss. y 548 y ss. 
aquéllos que de haber obrado con el debido cuidado (error vencible) no hubieran desconocido la antijuridicidad del hecho ${ }^{51}$.

Parece preferible, pues, considerar que el error de prohibición vencible determina únicamente una atenuación de la sanción porque hay una menor culpabilidad del sujeto. En materia de tráfico, dicha atenuación podría consistir, según los casos, en imponer la sanción correspondiente a la infracción inferior en grado (por ejemplo, si es muy grave imponer la sanción correspondiente a la grave) o la sanción en su grado mínimo (lo que es sólo posible en algunos tipos de infracciones, por cuanto que en otros la sanción la determina del forma fija el legislador; art. 67 LTSV). En cualquier caso, y desde el punto de vista de la política represiva, debe tenerse en cuenta que la solución es casi idéntica en uno y otro caso (subsistencia del dolo con atenuación de la sanción por ser menor la culpabilidad/desaparición del dolo pero calificación de la infracción como imprudente), ya que, de un lado, como casi todas las infracciones de tráfico admiten la forma imprudente (mejor dicho: son infracciones por imprudencia en cuanto que las normas del sector positivizan, como vimos, la diligencia exigible o el cuidado debido), el error vencible casi nunca determinará que la infracción quede impune y, de otro, los pocos supuestos en los que sólo cabe la forma dolosa (negativa a someterse a las pruebas de alcoholemia, a exhibir la documentación que ha de portarse en el vehículo, a identificar al conductor responsable de la infracción, etc.) es difícil poder apreciar un error de prohibición, dado el requerimiento previo por parte de los agentes de la autoridad o por los órganos encargados de la instrucción del procedimiento, en el que se les advertirá de la obligación legal que tienen de realizar tales comportamientos.

Para determinar la responsabilidad del sujeto en el error y, por tanto, la calificación del mismo como vencible o invencible, han de tenerse en cuenta una serie de circunstancias especialmente importantes en el sector del tráfico. Entre ellas debe destacarse, en primer lugar, el deber que pesa sobre determinados sujetos de recabar información y conocimientos jurídicos necesarios para desempeñar su actividad. De este modo, el error de prohibición es vencible cuando el sujeto no se esfuerza en alcanzar los conocimientos jurídicos necesarios, pese a que sabe que el sector en el que pretende actuar (como es el caso del tráfico) está sujeto a una regulación jurídica específica: como se ha dicho, "quien abre un banco o una tienda de comestibles, quien pretende explotar un negocio de hostelería o conducir un camión por la carretera sabe que para el ejercicio de estas actividades existen preceptos jurídicos espe-

51 Para salvar los inconvenientes que supone la consideración de que el error de prohibición vencible determina la impunidad cuando el delito o infracción de que se trate no admite la forma imprudente, se ha propuesto mantener una punición general de la imprudentia iuris, es decir, al margen de que el tipo concreto admita o no la forma imprudente, para el error vencible. Según esta interpretación, sostenida por S. Mir Puig, Derecho penal..., cit., pp. 554 y 558, el que el art. 14.3 CP remita a la pena inferior en uno o dos grados a la señalada para el delito doloso no equivale a que en caso de error vencible subsista el delito doloso, y dado que dicho precepto no alude para nada al fundamento de la atenuación de la pena, "no cabe excluir que dicha pena inferior pueda fundarse en la existencia de la imprudentia iuris (imprudencia de derecho) y la necesidad de su tratamiento diferenciado del de la imprudentia facti (imprudencia de hecho)". 
cíficos que tienen el objeto de excluir en la medida de lo posible los peligros inherentes a las mismas. Simplemente el saber esto ha de suponer para él ya un motivo para preocuparse por los preceptos jurídicos vigentes en ese sector. Este es el terreno de errores de prohibición vencibles precisamente para el Derecho penal especial o accesorio, en el que en los demás casos es más disculpable un desconocimiento de la situación jurídica. Ello rige sobre todo para las distintas profesiones y oficios" ${ }_{52}$. Como se ve, no se trata de una peculiaridad del Derecho administrativo sancionador como han pretendido algunos, sino que las circunstancias profesionales o de otro tipo también se tienen en cuenta en el ámbito penal para determinar la vencibilidad o no del error. Lo que ocurre es que en el Derecho administrativo sancionador tales circunstancias son mucho más frecuentes que en el Derecho penal. Piénsese en el sector del tráfico, en el que prácticamente todos los sujetos responsables de las infracciones de tráfico (art. 72 LTSV) se encuentran en dicha situación: conductores de vehículos de motor, titulares o propietarios de los mismos, fabricantes de automóviles, titulares y personal de las autoescuelas y centros de reconocimiento, etc. ${ }^{53}$. La diferencia en una y otra rama en este aspecto es puramente cuantitativa.

Debe tenerse en cuenta, además, que las propias normas específicas que regulan el tráfico no sólo exigen unos conocimientos específicos para desarrollar determinadas actividades, sino que, además, establecen el deber de mantener al día tales conocimientos. La conducción de vehículos a motor, por ejemplo, exige haber obtenido el permiso o licencia de conducción, "que se dirigirá a verificar que los conductores tengan los requisitos de capacidad, conocimientos y habilidad necesarios para la conducción" (art. 60.1 LTSV), entre los cuales cabe destacar la posesión y demostración de que se posee "un conocimiento razonado y una buena comprensión" de "las disposiciones legales y reglamentarias en materia de tráfico, circulación de vehículos a motor y seguridad vial" [art. 47.1 y Anexo V.B) 1 y 2 del Reglamento General de Conductores]; requisito de conocimiento que se debe poseer durante todo el tiempo de vigencia de la autorización ya que la validez de la misma "estará subordinada a que se mantengan los requisitos exigidos para su otorgamiento" (art. 63.3 LTSV).

Otra circunstancia relevante a efectos del error de prohibición es la peligrosidad que entraña la actividad que se desarrolla, que exige un mayor grado de diligencia, y la consciencia de que la misma es perjudicial para los demás. Se ha señalado que un

52 C. Roxin, Derecho penal..., cit., p. 886.

53 La STS de 8 de mayo de 1987 (Ar. 3570) desestima el error alegado por el infractor precisamente porque su "condición de conductor profesional le hace especialmente conocedor de los requisitos y obligaciones de toda índole inherentes a la compraventa de vehículos. No cabe presumir desconocimiento en quien tiene su modo de vida precisamente en este sector". Sobre la incidencia de la condición de profesional o lego en el error de prohibición, M. Rebollo Puig, Potestad..., cit., pp. 670 y ss.; A. Nieto García, Derecho..., cit., págs 364, de quien tomo la referencia de la sentencia citada (p. 370); A. de Palma del Teso, El principio..., cit., p. 172. En la jurisprudencia, SAN de 14 de diciembre de 2006 (Ar. 215 de 2007), STSJ de Navarra, de 15 de enero de 1998 (Ar. 81), STSJ de Castilla- La Mancha de 3 de noviembre de 1999 (Ar. 4080), SAN de 19 de diciembre de 2008 (recurso núm. 112/2007), STSJ de Cataluña de 28 de marzo de 2000 (Ar. $116 \quad \begin{aligned} & \text { 593), etc. To } \\ & \text { pp. 328-331. }\end{aligned}$ 
error de prohibición es vencible cuando el sujeto es consciente de que perjudica a otros o a la colectividad ${ }^{54}$. El conductor que sabe que conduce de forma negligente $o$ temeraria o tiene conocimiento de la presencia de una accidente con víctimas y no para, no puede alegar error de prohibición pues sabe que su comportamiento es perjudicial. La propia normativa reguladora del tráfico le exige como requisito de obtención del permiso y de su mantenimiento "dominar el vehículo con el fin de no crear situaciones peligrosas y reaccionar de forma apropiada cuando éstas se presenten", "discernir los peligros originados por la circulación y valorar su gravedad", etc. [art. 42. b) y c) del Reglamento General de Conductores].

La tolerancia de una conducta por parte de la Administración cuando de aquélla cabe concluir que la propia Administración juzga la conducta conforme a Derecho puede fundamentar un error invencible. Por ejemplo, la tolerancia o permisión por parte de las autoridades de tráfico de un determinado exceso en los límites de velocidad $^{55}$. Pero no cuando se trata de la mera tolerancia de un abuso: por ejemplo, el frecuente y lamentable estacionamiento en doble fila o en carriles reservados a determinados vehículos.

Lo mismo cabe decir de una información facilitada por la Administración sobre la conformidad a Derecho de un determinado comportamiento (error inducido). Si la propia Administración informa a través de Revistas con cierto aire oficial que es lícita la conducción de vehículos portando únicamente fotocopias compulsadas de los permisos de conducir y circulación, luego no puede sancionar a quienes utilicen tales fotocopias con el argumento de que la información era incorrecta, ya que los conductores confían en la información que se les ha facilitado y, por tanto, su error de prohibición es invencible ${ }^{56}$. Si la Administración quiere evitar dicho error debe informar de forma clara y durante un tiempo razonable de su cambio de criterio u opinión, de modo que los interesados puedan tener la posibilidad de conocer lo que está prohibido. Es, entiendo, lo que debería hacer respecto de la tolerancia en el exceso de velocidad y en la utilización de fotocopias compulsadas de los referidos documentos, mientras que en el caso de los estacionamientos en doble y triple fila -y en otros muchos ejemplos que

54 C. Roxin, Derecho penal..., cit., p. 887.

55 También podría sostenerse en tal caso la atipicidad de la conducta (o su falta de antijuridicidad) en aplicación del denominado principio de insignificancia (Sobre esto, S. Mir Puig, Derecho penal..., cit., p. 532). Desde la teoría general del Derecho, M. Atienza y J. Ruiz Manero, Ilícitos atípicos, Madrid, Trotta, 2000, consideran que un ejemplo como el propuesto constituye un caso de tolerancia jurídica que determina un supuesto de "licitud atípica": conductas que aparecen prima facie como prohibidas, por resultar subsumibles en una regla prohibitiva pero que, a la luz de los principios relevantes del sistema jurídico (en concreto el principio de tolerancia), resulta finalmente permitidas (p. 115). Cuestión distinta, como señalan acertadamente estos autores, es que, en casos como el planteado, se aplique mal dicho principio, esto es, que la se tolere lo que no se debería tolerar.

56 Respecto de las fotocopias del permiso y licencia de conducción, lo exigible es, entiendo, la utilización de copias auténticas como se despende del art. 46.2 de la Ley 30/1992, de 26 de noviembre, de Régimen Jurídico de las Administraciones Públicas y del Procedimiento Administrativo Común y del Real Decreto 772/1999, de 7 de mayo, que regula la presentación de escritos y solicitudes ante la Administración General del Estado, la expedición de copias de documentos y la devolución de originales. 
podrían traerse a colación- lo que debería hacer, sin más, es vigilar, exigir el cumplimiento inmediato de las normas y castigar si las mismas no se cumplen.

En estos casos de error inducido, de forma activa o pasiva, por la propia Administración los Tribunales suelen aplicar el principio de confianza legítima, como puede verse, entre otras, en las STS de 14 de febrero de 2006 (recurso 4628/2003) y de 26 de diciembre de 2007 (Ar. 370 de 2008) en las que se exige para apreciar su existencia que la convicción del particular se base en signos externos de la Administración suficientemente concluyentes y que se tengan en cuenta todas las circunstancias concurrentes en cada supuesto (comportamiento de la Administración, conducta sanciona$\mathrm{da}$, intereses generales y particulares en juego, etc. $)^{57}$

Por último hay que señalar que también se ha considerado que son suficientes para considerar invencible un error de prohibición, la consulta a un abogado y el seguimiento de su opinión, la confianza en la jurisprudencia uniforme sobre una cuestión o, incluso, cuando el contenido de la norma resulta ambiguo y escoge una entre varias posibilidades de interpretación ${ }^{58}$. En el sector del tráfico pueden plantearse supuestos en los que será preciso acudir a tales soluciones, particularmente en aquellas materias en las que abundan normas sancionadoras en blanco y conceptos jurídicos indeterminados.

\section{La prueba de la inimputabilidad}

El derecho constitucional a la inocencia comporta que la sanción que impone la Administración debe basarse "en actos o medios probatorios de cargo o incriminadores de la conducta reprochada; que la carga de la prueba corresponde a quien acusa, sin que nadie esté obligado a probar su propia inocencia, y que cualquier insuficiencia en el resultado de las pruebas practicadas, libremente valorado por el órgano sancionador, debe traducirse en un pronunciamiento absolutorio [SSTC 76/1990, 169/1998, 20/2008, etc.]. Es pues la Administración la que debe probar la culpabilidad (que se ha cometido un comportamiento típico, antijurídico y culpable) y no el presunto infractor su inocencia. De lo cual no cabe deducir, como algunos hacen erróneamente, que la exigencia de dolo y culpa en las infracciones deriva o se deduce de la presunción de inocencia.

Buena parte de la doctrina, sin embargo, así como la jurisprudencia mayoritaria, exigen, tanto en el proceso penal, como en el procedimiento administrativo sancionador, que el acusado pruebe la concurrencia de circunstancias eximentes y extintivas de la responsabilidad ${ }^{59}$. Pero no es esto exactamente lo que el acusado ha de

57 Vid. M. Izquierdo Carrasco, "La culpabilidad y los sujetos responsables", cit., pp. 346-347.

58 C. Roxin, Derecho penal..., cit., pp. 888 y 890-891. También se refiere al último supuesto, citando 118 sentencias del TS al respecto, I. Pemán Gavin,
59 STS de 10 de diciembre de 2002 
probar, pues con arreglo al principio de presunción de inocencia no sería admisible que el acusado pruebe un hecho negativo (su inocencia). Se trata más bien de que una vez que la Administración ha presentado una prueba de cargo suficiente para desvirtuar la presunción de inocencia, el acusado tiene ahora la carga de aportar medios de prueba que, cuando menos, creen en el juzgador alguna duda razonable acerca de la existencia de las circunstancias relativas a su culpabilidad. No tiene por ello que probar la concurrencia de las causas de inimputabilidad, como a veces se afirma, sino que le bastará con generar una duda razonable en el juzgador en torno a la concurrencia de tales circunstancias para que resulte absuelto o sea reducida la gravedad de su sanción ${ }^{60}$. La STS de 12 de enero de 2000 (recurso 8305/1995) parece apuntar esta idea cuando señala que:

"acreditada la conducta o participación que constituye el soporte de la infracción, la apreciación del requisito de la culpabilidad deriva hacia la acreditación psicológica de la imputabilidad y dicha imputabilidad es de aceptar mientras no conste ningún hecho o circunstancia con entidad bastante para eliminarla. En el caso que se está enjuiciando, no consta ningún hecho que acredite que las personas, que en calidad de agentes de la sociedad realizaron la conducta sancionada, tuvieran perdidas o disminuidas sus facultades cognoscitivas y volitivas en términos suficientes para descartar en ellas la imputabilidad de la que resulta la culpabilidad”.

Como atinadamente se ha señalado para el ámbito penal, pero la solución ha de ser aquí la misma, "sería erróneo deducir de la presunción de inocencia que en todo proceso penal, para que proceda la condena, deba hacerse efectivamente prueba de la no existencia de todas las diversas circunstancias que excluyen la punibilidad [... ] Lo que ocurre es que, por el conjunto de las demás pruebas, el juzgador queda efectivamente convencido de la no concurrencia de las causas de exención, o al menos, que no planteándoselo o surgiendo el problema, falla sin vacilación alguna en este punto. Por lo mismo, una sentencia condenatoria no necesita decir en su relación de hechos probados que se ha probado que el procesado es imputable, que ha obrado voluntariamente, que no ha obrado en estado de necesidad, que no ha prescrito el delito, etc." ${ }^{61}$.

Recibido: 8 de junio de 2010

Aceptado: 14 de julio de 2010

60 L. Rosenberg, La carga de la prueba, cit., pp. 44-45; E. Gómez Orbaneja y V. Herce Quemada, Derecho procesal penal, $10^{a}$ ed., Madrid, 1987, p. 281, I. Diez-Picazo Giménez, “Artículo 24: Garantías procesales”, en O. Alzaga Villaamil, Comentarios a la Constitución española de 1978, Tomo III, Madrid, Cortes Generales-Editoriales de Derecho Reunidas, 1996, p. 114; M. Fernández López, Prueba y presunción de inocencia, Madrid, lustel, 2005, pp. 226 y ss.; L. Alarcón Sotomayor, El procedimiento administrativo sancionador y los derechos fundamentales, Madrid, Civitas, 2007, pp. 398 y ss.

61 E. Gómez Orbaneja y V. Herce Quemada, Derecho procesal penal, cit., pp. 281-282. 
